\title{
Distributions and sea-to-air fluxes of nitrous oxide in the South China Sea and the West Philippines Sea
}

\author{
Hsiao-Chun Tseng ${ }^{\mathrm{a}, \mathrm{b}}$, Chen-Tung Arthur Chen ${ }^{\mathrm{b}, *}$, Alberto V. Borges ${ }^{\mathrm{c}}$, T. Angel DelValls ${ }^{\mathrm{a}}$, \\ Chao-Ming Lai ${ }^{\mathrm{d}}$, Ting-Yu Chen ${ }^{\mathrm{b}}$ \\ a UNESCO UNITWIN/WiCop. Physical Chemistry Department. Faculty of Marine and Environmental Sciences. Polígono río San Pedro s/n, University of Cadiz, \\ 11519 Puerto Real, Cadiz, Spain \\ ${ }^{\mathrm{b}}$ Department of Oceanography, National Sun Yat-sen University, Kaohsiung 804, Taiwan \\ c Université de Liège, Unité d'Océanographie Chimique, Institut de Physique (B5), B-4000, Belgium \\ d Departmentt of Agricultural Chemistry, National Taiwan University, Taipei 106, Taiwan
}

\section{A R T I C L E I N F O}

\section{Article history:}

Received 25 February 2016

Received in revised form

13 June 2016

Accepted 15 June 2016

Available online 17 June 2016

\section{Keywords:}

South China Sea

West Philippines Sea

$\mathrm{N}_{2} \mathrm{O}$

Excess $\mathrm{N}_{2} \mathrm{O}$

\begin{abstract}
A B S T R A C T
Approximately 600 water samples from the South China Sea (SCS) and 250 water samples from the West Philippines Sea (WPS) were collected during seven cruises from August 2003 to July 2007 to determine nitrous oxide $\left(\mathrm{N}_{2} \mathrm{O}\right)$ distributions between the surface and a maximum depth of $4250 \mathrm{~m}$. In the SCS, the average surface $\mathrm{N}_{2} \mathrm{O}$ concentration exceeded the atmospheric equilibrium concentration (on average $132 \pm 23 \%$ ); however in the WPS, the surface $\mathrm{N}_{2} \mathrm{O}$ concentration was lower than the atmospheric equilibrium concentration (on average $90 \pm 22 \%$ ). The $\mathrm{N}_{2} \mathrm{O}$ concentration reached a maximum $\left(\sim 23 \mathrm{nmol} \mathrm{L}^{-1}\right)$ in the WPS at 800-1000 m, and $\left(\sim 28 \mathrm{nmol} \mathrm{L}^{-1}\right)$ at a shallower depth of around 600$800 \mathrm{~m}$ in the SCS, owing to vertical mixing and intensive upwelling in the SCS. In the SCS, the surface $\mathrm{N}_{2} \mathrm{O}$ concentration was $7.59 \pm 1.32 \mathrm{nmol} \mathrm{L}^{-1}$ and the calculated sea-to-air flux was $5.5 \pm 3.9 \mu \mathrm{mol} \mathrm{m}^{-2} \mathrm{~d}^{-1}$. The surface $\mathrm{N}_{2} \mathrm{O}$ concentration in the WPS, $5.19 \pm 1.26 \mathrm{nmol} \mathrm{L}^{-1}$, was lower than that in the SCS. The WPS is a sink for $\mathrm{N}_{2} \mathrm{O}$ and the calculated sea-to-air flux was $-1.7 \pm 3.9 \mu \mathrm{mol} \mathrm{m}^{-2} \mathrm{~d}^{-1}$. The SCS emitted $19.3 \times 10^{6} \mathrm{~mol} \mathrm{~d}^{-1} \mathrm{~N}_{2} \mathrm{O}$ to the atmosphere and exported $8.5 \times 10^{6} \mathrm{~mol} \mathrm{~d}^{-1} \mathrm{~N}_{2} \mathrm{O}$ to the WPS during the wet season.
\end{abstract}

(c) 2016 Elsevier Ltd. All rights reserved.

\section{Introduction}

Nitrous oxide $\left(\mathrm{N}_{2} \mathrm{O}\right)$ is a trace gas that strongly influences the climate and atmospheric chemistry. It is a long-lived and powerful greenhouse gas (Prather et al., 2012), ranking third in anthropogenic radiative forcing, only behind carbon dioxide $\left(\mathrm{CO}_{2}\right)$ and methane $\left(\mathrm{CH}_{4}\right)$ (Myhre et al., 2013). Additionally, $\mathrm{N}_{2} \mathrm{O}$ has a global warming potential in a 100 -year time frame $\left(\mathrm{GWP}_{100}\right)$ that is 298 times that of $\mathrm{CO}_{2}$ (IPCC, 2013). Atmospheric concentrations of $\mathrm{N}_{2} \mathrm{O}$ have risen from $270 \pm 7 \mathrm{ppb}$ in 1750-324.2 $\pm 0.1 \mathrm{ppb}$ in 2011 (IPCC, 2013). The gas also affects the climate by interacting with the stratospheric ozone (Crutzen, 1974; Nevison and Holland, 1997; Prather et al., 2001) as the $\mathrm{N}_{2} \mathrm{O}$ in the stratosphere is an important precursor of nitric oxide (NO) radicals, which are involved in the depletion of the atmospheric ozone (Crutzen, 1970; Ravishankara, et al., 2009). Since 2011, $\mathrm{N}_{2} \mathrm{O}$ has become the dominant ozonedepleting substance on account of the decrease in the impact of

\footnotetext{
* Corresponding author.

E-mail address: ctchen@mail.nsysu.edu.tw (C.-T. Chen).
}

dichlorodifluoromethane (CFC-12) after the implementation of the Montreal Protocol and amendments (Ravishankara et al., 2009).

Natural sources of $\mathrm{N}_{2} \mathrm{O}$ include oceans, sediments, inland waters, and terrestrial soils. However, global inventories of these sources are still fairly uncertain. According to the Fifth Assessment Report of the Intergovernmental Panel on Climate Change (IPCC $5 A R$ ), the oceans are significant sources of the atmospheric $\mathrm{N}_{2} \mathrm{O}$, and account for approximately one-third of global natural emissions and one-fifth of total (natural and anthropogenic) emissions. Nevison et al. (1995) computed a global ocean source of $4 \mathrm{Tg} \mathrm{N}$ $\mathrm{yr}^{-1}$, with a large range of uncertainty from 1.2 to $6.8 \mathrm{Tg} \mathrm{N} \mathrm{yr}^{-1}$ based on 60,000 at-sea measurements. Model-derived estimates also vary widely, between 1.7 and $8 \mathrm{Tg} \mathrm{N} \mathrm{yr}^{-1}$ (Nevison et al., 2003; Suntharalingam and Sarmiento, 2000). Recently, Manizza et al. (2012) used a large-scale ocean general circulation model that was coupled with a biogeochemical model to quantify mean ocean emissions at $4.5 \mathrm{TgN} \mathrm{yr}^{-1}$, while Saikawa et al. (2014) estimated an oceanic $\mathrm{N}_{2} \mathrm{O}$ source with a flux of between 3.6 and $5.2 \mathrm{TgN}^{-1}{ }^{-1}$, based on a global atmospheric inversion model. These large uncertainties arise from too few observations and poor 
knowledge of mechanisms of $\mathrm{N}_{2} \mathrm{O}$ formation, reflecting a general lack of understanding of key aspects of the oceanic nitrogen cycle (Gruber and Galloway, 2008; Zehr and Ward, 2002), and of $\mathrm{N}_{2} \mathrm{O}$ in particular (e.g., Bange et al., 2009; Freing et al., 2012; Zamora et al., 2012, among others).

Most $\mathrm{N}_{2} \mathrm{O}$ in oceanic environments is formed from $\mathrm{NH}_{2} \mathrm{OH}$ as a byproduct of nitrification $\left(\mathrm{NH}_{4}{ }^{+} \rightarrow \mathrm{NH}_{2} \mathrm{OH} \rightarrow \mathrm{NO}_{2}{ }^{-} \rightarrow \mathrm{NO}_{3}{ }^{-}\right.$) and as an intermediate product during denitrification $\left(\mathrm{NO}_{3}{ }^{-} \rightarrow \mathrm{NO}_{2}{ }^{-}\right.$ $\rightarrow \mathrm{N}_{2} \mathrm{O} \rightarrow \mathrm{N}_{2}$ ). During autotrophic nitrification $\mathrm{N}_{2} \mathrm{O}$ can be formed by $\mathrm{NH}_{4}{ }^{+} \rightarrow \mathrm{NH}_{2} \mathrm{OH}(\rightarrow \mathrm{NO}) \rightarrow \mathrm{NO}_{2}{ }^{-}$either via the pathways $\mathrm{NH}_{2} \mathrm{OH} \rightarrow \mathrm{N}_{2} \mathrm{O}$ and $\mathrm{NO} \rightarrow \mathrm{N}_{2} \mathrm{O}$ (Arp and Stein, 2003; Stein and Yung, 2003) or via the pathway $\mathrm{NO}_{2}{ }^{-} \rightarrow \mathrm{NO} \rightarrow \mathrm{N}_{2} \mathrm{O}$ (the latter is part of the so-called nitrifier-denitrification process) (Stein and Yung, 2003; Wrage et al., 2001). Nitrification is believed to be the main contributor to the production of $\mathrm{N}_{2} \mathrm{O}$ in seawater (Najjar, 1992; Bange and Andreae, 1999; Freing et al., 2012). Denitrification occurs under low oxygen $\left(<6 \mu \mathrm{mol} \mathrm{L}^{-1}\right)$ to anoxic conditions (Nevison et al., 2003). Denitrification produces and consumes $\mathrm{N}_{2} \mathrm{O}$ in oxygen minimum zones and the net result is that oxygen minimum zones have some of the highest $\mathrm{N}_{2} \mathrm{O}$ concentrations in the ocean (LaMontagne et al., 2003; Naqvi et al., 2010; Zamora et al., 2012; Arévalo-Martínez et al., 2015). In the water column with low oxygen concentrations and in sediments or inside suspended particles, nitrification and denitrification can occur simultaneously and are often closely coupled (Seitzinger, 1988; Ward et al., 1989; Capone, 1991; Middelburg et al., 1996; Barnes and Owens, 1998; Naqvi et al., 1998; Robinson et al., 1998; Usui et al., 2001; Nevison et al., 2003; Codispoti et al., 2005; Bange, 2008). The yield of $\mathrm{N}_{2} \mathrm{O}$ from both processes is highly dependent on the concentration of dissolved oxygen (Goreau et al., 1980; de Bie et al., 2002; Naqvi et al., 2010).

Few investigations of $\mathrm{N}_{2} \mathrm{O}$ in the South China Sea (SCS) have been published, and these have only considered the northern part (Xu et al., 2006; Zheng et al., 2009; Han et al., 2013). Almost no data on $\mathrm{N}_{2} \mathrm{O}$ in the West Philippines Sea (WPS) are available. This paper presents the spatial and vertical distributions of $\mathrm{N}_{2} \mathrm{O}$ in the water columns of the SCS and the WPS as well as the sea-to-air fluxes. The differences between these seas and the influencing factors are discussed. Additionally, previous research in the SCS calculated the excess $\mathrm{N}_{2} \mathrm{O}\left(\Delta \mathrm{N}_{2} \mathrm{O}\right)$ concentration by using "the contemporary atmospheric mole fraction" throughout the water column. This study for the first time calculates the $\Delta \mathrm{N}_{2} \mathrm{O}$ by using "the initial atmospheric mole fraction" to reduce the uncertainty of $\Delta \mathrm{N}_{2} \mathrm{O}$.

\section{Study area}

The SCS is the largest marginal sea in the world with an area of $3.5 \times 10^{6} \mathrm{~km}^{2}$ and an average depth of $1350 \mathrm{~m}$. At the southern edge of the SCS lies the Sunda Shelf, which has a mean depth of around $50 \mathrm{~m}$ and is connected to the Straits of Malacca. The Mindoro Strait connects the eastern SCS with the Sulu Sea and the Taiwan Strait connects the northern SCS with the East China Sea. The northeastern SCS is connected with the WPS via the Luzon Strait, which has the deepest sill of any that connects the SCS with any adjacent bodies of water. As the Luzon Strait is $2200 \mathrm{~m}$ deep, the surface and intermediate waters are exchanged freely between the SCS and the WPS. Whereas waters that are deeper than $2200 \mathrm{~m}$ in the WPS cannot enter the SCS. Consequently, waters deeper than $2200 \mathrm{~m}$ in the SCS are relatively homogeneous, with hydrochemical properties that are similar to those of the water at $2200 \mathrm{~m}$ in the WPS (Chen et al., 2006).

The WPS is located in the western part of the North Pacific with an average depth of around $5500 \mathrm{~m}$, and it is bordered by the Japanese islands of Honshu, Shikoku, and Kyushu to the north, the
Ryukyu Islands to the northwest, Taiwan to the west, the Philippine archipelago to the southwest, and the Izu-Ogasawara Ridge and the Mariana Ridge to the east. The Kyushu-Palau Ridge (at a longitude of around $135^{\circ} \mathrm{E}$ ) separates the West Mariana Basin from the WPS. This study focuses on the region between $120.5^{\circ} \mathrm{E}$ and $126.5^{\circ} \mathrm{E}$ and between $21^{\circ} \mathrm{N}$ and $26^{\circ} \mathrm{N}$, where the WPS connects with the SCS and a significant quantity of water is frequently exchanged.

The Asian monsoon dominates climatic variations at the sea-air interface of the SCS. The southwest monsoon season runs from May to October and brings extensive precipitation; it is the wet season in Southeast Asia. The northeast monsoon season runs from November to April and is characterized by high wind speeds (Han, 1998). The seven cruises herein were all conducted during the wet season.

\section{Materials and methods}

\subsection{Sample collections}

Samples were taken during five cruises on board R/V Ocean Researchers I and III in the SCS (Fig. 1a; Table 1), designated ORIII896 (August 2003), ORI-695 (September 2003), ORIII-983 (July 2004), ORI-802 (July 2006), and ORI-837 (July 2007).

Samples were collected close to the south of the Taiwan Strait, which is located in the northeastern part of the SCS, during the cruises in August 2003 (ORIII-896) and July 2004 (ORIII-983). ORI695 was conducted near the Pearl River estuary and was influenced by the summer estuarine plume (Gan et al., 2009; Cao et al., 2011; Han et al., 2012; Zhai et al., 2013; Bai et al., 2015). The Pearl River (Zhujiang) is the 13th largest river in the world (Yin et al., 2004) and the second largest river in China (after the Yangtze River) with a water discharge of $326 \times 10^{9} \mathrm{~m}^{3}$ annually; it is also the second largest river (after the Mekong River) that enters the SCS (Chen et al., 2008).

In July 2006 (ORI-802), samples were taken on the Sunda Shelf and on the continental slope, where the depth increases sharply. From July 16-31 of 2007 (ORI-837), surface water samples were taken from the Luzon Strait and along the western coast of Luzon Island, Palawan Island, and the northwestern coast of Borneo Island; profile water samples were taken at various depths from the eastern part of the SCS to the southern part of the SCS.

Samples were obtained from the WPS during three of the cruises (Fig. 1b; Table 1). Profile water samples were taken at various depths on ORI-725 (August 2004) and ORIII-1149 (May 2006). These two cruises were conducted along $22^{\circ} \mathrm{N}$ from $120.5^{\circ} \mathrm{E}$ to $126.5^{\circ} \mathrm{E}$ in August 2004 and from $120.5^{\circ} \mathrm{E}$ to $124^{\circ} \mathrm{E}$ in May 2006 , respectively. Surface water samples were taken from the northeastern coast of Taiwan to the Luzon Strait on ORI-725 (August 2004) and ORI-837 (July 2007).

Water samples were collected from various areas and depths using a Rosette sampler that was fitted with $5 \mathrm{~L}$ or $10 \mathrm{~L}$ Niskin bottles along with a conductivity-temperature-depth (CTD) probe (Sea-Bird 911, USA). Saturated $\mathrm{HgCl}_{2}$ was added to all samples to inhibit microbial activity, excluding those that were used to measure salinity. Temperature data were obtained from the CTD profiles, whereas the salinity values that were used in the analysis were determined from discrete AUTOSAL measurements.

Water samples that were used to measure $\mathrm{N}_{2} \mathrm{O}$ concentration were collected in $120 \mathrm{ml}$ dark glass bottles. The bottles were rinsed three times using the sampled water. After one fold of bottle volume was allowed to overflow the bottle, $10 \mathrm{ml}$ of the water sample was withdrawn from the bottle to leave an air space and $0.5 \mathrm{ml}$ saturated $\mathrm{HgCl}_{2}$ was then added. The sample bottles were then immediately sealed with a butyl rubber stopper and an 
(a)

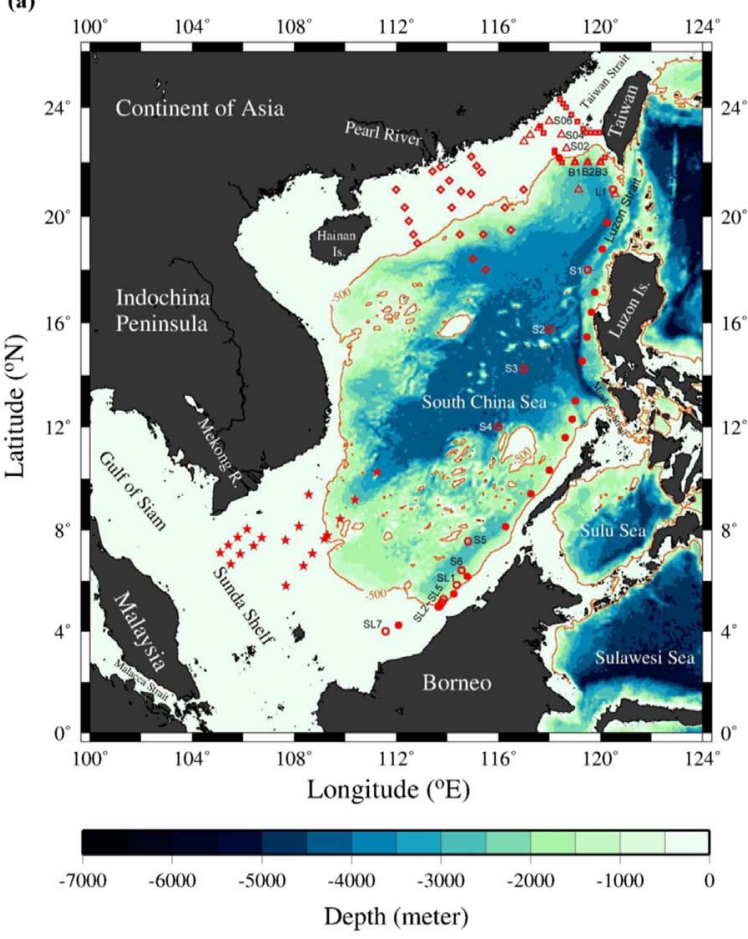

(b)

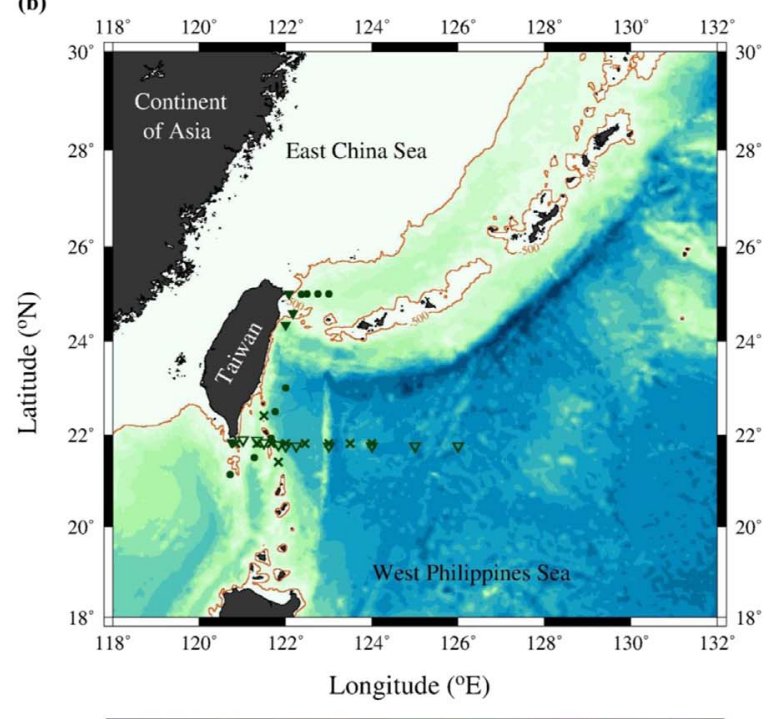

$-11000-10000-9000-8000-7000-6000-5000-4000-3000-2000-1000 \quad 0$

Depth (meter)

Fig. 1. Study area and station locations: (a) South China Sea stations. (surface sampling stations, •: ORI-837 (Jul. 2007); profile sampling stations, $\Delta$ : ORIII-896 (Aug. 2003), $\diamond$ : ORI-695 (Sep. 2003), ㅁ: ORIII-983 (Jul. 2004), «t: ORI-802 (Jul. 2006), ०: ORI-837 (Jul. 2007); (b) West Philippines Sea stations. (surface sampling stations, $\mathbf{~ : ~ O R I - 7 2 5 ~ ( A u g . ~ 2 0 0 4 ) , ~ \bullet : ~ O R I - 8 3 7 ~ ( J u l . ~ 2 0 0 7 ) ~ - S t n . ~ A - D ; 1 - 5 ; ~ p r o f i l e ~}$ sampling stations, $\nabla$ : ORI-725 (Aug. 2004), $\times$ : ORIII-1149 (May 2006)).

aluminum cap. The samples were stored in a dark box at $4{ }^{\circ} \mathrm{C}$. All water samples were transferred to a laboratory and analyzed within three months of collection.

\subsection{Chemical analysis}

The salinity of the water samples was determined by measuring the conductivity using an AUTOSAL salinometer (Guildline Instruments), which was calibrated using the standard seawater (batch no. P141) from the International Association for the Physical Sciences of the Oceans (IAPSO). The precision of the salinity measurements was \pm 0.003 . Chlorophyll $a$ samples were collected by filtration through a $0.45 \mu \mathrm{m}$ diameter Millipore polycarbonate filter. A Turner Designs model 10-AU fluorometer (Varian Eclipse) was utilized to measure chlorophyll $a$ concentration following extraction by $90 \%$ acetone (Strickland and Parsons, 1972) with a precision of $\pm 5 \%$. Dissolved oxygen (DO) concentration was measured by the direct spectrophotometry (Pai et al., 1993) with a precision of about $\pm 0.32 \%$ at the $190 \mu \mathrm{mol} \mathrm{L}^{-1}$ level. The apparent oxygen utilization (AOU) was calculated using the oxygen solubility equation of Chen (1981), as a function of salinity and temperature. Nitrate $\left(\mathrm{NO}_{3}{ }^{-}\right)$plus nitrite $\left(\mathrm{NO}_{2}{ }^{-}\right)$concentration was measured by the pink azo dye method (Strickland and Parsons, 1972) using a flow injection analyzer and an online Cd coil. The precision of this method was around $\pm 1 \%$ at $35 \mu \mathrm{mol} \mathrm{L}^{-1}$, and $\pm 3 \%$ at $1 \mu \mathrm{mol} \mathrm{L}{ }^{-1}$. The $\mathrm{NO}_{2}{ }^{-}$concentration was also obtained by the pink azo dye method (Strickland and Parsons, 1972; Pai et al., 1990) using a flow injection analyzer, yielding a precision of $\pm 0.02 \mu \mathrm{mol} \mathrm{L}^{-1}$.

The concentration of dissolved $\mathrm{N}_{2} \mathrm{O}$ was estimated using the modified headspace equilibrium method (Johnson et al., 1990) with gas chromatographs (GC; Varian 3600 and 3800) that were equipped with electron capture detectors (ECD). The samples were placed in a water bath at a constant temperature of $25^{\circ} \mathrm{C}$, and allowed to equilibrate for at least three hours. Two $\mathrm{ml}$ of the gas from the headspace was injected into the GC. The GC-ECD had a $3.6 \mathrm{~m} \times 1 / 8 \mathrm{in}$. stainless steel column, which was filled with $80 /$ 100 mesh Porapak Q. The ECD was calibrated with pure $\mathrm{N}_{2}$ (JingShang, Taiwan) and two commercial gas mixtures with an $\mathrm{N}_{2} \mathrm{O}$ mixing ratio of 1.0 ppmv (Scott Specialty Gases, U.S.A.) and 2.5 ppmv (All-Win, Taiwan). The precision of the repeated routine analysis of water samples was approximately $\pm 5 \%$ of the concentration of $\mathrm{N}_{2} \mathrm{O}$. To acquire the calibration curve, airtight bags were used to mix pure $\mathrm{N}_{2}$ with two standard gases to reach $\mathrm{N}_{2} \mathrm{O}$ concentrations of $0,0.25,0.5,0.75,1,1.5,2$, and $2.5 \mathrm{ppmv}$ for calibration of the GC-ECD. Each calibration curve had $a \mathrm{R}^{2}>0.999$. The $\mathrm{N}_{2} \mathrm{O}$ concentration in the headspace of our samples were measured and followed the modified headspace equilibrium method (Johnson et al., 1990), as follows:

$$
\begin{aligned}
\mathrm{C}_{\text {seawater }}= & {\left[\mathrm{C}_{\text {headspace gas }}\left((\beta / 24.3) \mathrm{RT}+\mathrm{V}_{\text {gas }} / \mathrm{V}_{\text {seawater }}\right)\right.} \\
& \left.-\mathrm{C}_{\text {air }} * \mathrm{~V}_{\text {gas }} / \mathrm{V}_{\text {seawater }}\right] / 24.3
\end{aligned}
$$

Where $\mathrm{C}_{\text {seawater }}$ is $\mathrm{N}_{2} \mathrm{O}$ concentration in the seawater; $\mathrm{C}_{\text {headspace gas }}$ is $\mathrm{N}_{2} \mathrm{O}$ concentration in the headspace gas; $\beta$ is Bunsen solubility of $\mathrm{N}_{2} \mathrm{O} ; 24.3$ is the molar volume of $\mathrm{N}_{2} \mathrm{O}$ in $\mathrm{L} \mathrm{mol}^{-1}$; $\mathrm{R}$ is the gas constant in $\mathrm{Latm} \mathrm{mol}{ }^{-1} \mathrm{~K}^{-1}$; $\mathrm{T}$ is in $\mathrm{K} ; \mathrm{V}_{\text {gas }}$ is the volume of the gas phase; $V_{\text {seawater }}$ is the volume of the liquid phase; and $C_{a i r}$ is atmospheric $\mathrm{N}_{2} \mathrm{O}$ concentration. The calibration curve was used to calculate the $\mathrm{N}_{2} \mathrm{O}$ concentration in the headspace and then the $\mathrm{N}_{2} \mathrm{O}$ concentration in the seawater was calculated according to the above equation. The highest $\mathrm{N}_{2} \mathrm{O}$ concentrations of the headspace gas was around $2.5 \mathrm{ppm}$. The $\mathrm{N}_{2} \mathrm{O}$ concentrations of the headspace gas fitted in our calibration curve.

\subsection{Saturation ratio}

The concentrations of the $\mathrm{N}_{2} \mathrm{O}$ in the water samples were obtained from those that were measured in the headspace by subtracting the influence of atmospheric $\mathrm{N}_{2} \mathrm{O}$ and using Bunsen coefficients to calculate the equilibrium solubilities, as described by Weiss and Price, (1980).

The atmospheric $\mathrm{N}_{2} \mathrm{O}$ concentrations were taken from the NOAA/ESRL in situ program (http://www.esrl.noaa.gov/gmd). The annual average atmospheric $\mathrm{N}_{2} \mathrm{O}$ concentrations at Mauna Loa 
Table 1

Seven research cruises were conducted in the SCS and the WPS.

\begin{tabular}{|c|c|c|c|c|c|c|}
\hline \multicolumn{2}{|c|}{ Study area } & \multirow[t]{2}{*}{ Date } & \multirow[t]{2}{*}{ Cruise } & \multirow[t]{2}{*}{ Station } & \multicolumn{2}{|c|}{ Surface $\mathrm{N}_{2} \mathrm{O}(\mathrm{nM})$} \\
\hline & & & & & Range & Average \\
\hline \multirow[t]{5}{*}{ SCS } & The northeastern SCS & Aug. 2003 & ORIII-896 & 11 & $7.72-14.20$ & $10.33 \pm 1.93$ \\
\hline & Pearl River estuary & Sep. 2003 & ORI-695 & 22 & $6.30-8.29$ & $7.45 \pm 0.55$ \\
\hline & The northeastern SCS & July 2004 & ORIII-983 & 22 & $6.74-10.30$ & $7.96 \pm 0.84$ \\
\hline & The southwestern SCS & Jul. 2006 & ORI-802 & 20 & $5.52-7.84$ & $6.84 \pm 0.60$ \\
\hline & The eastern and southern SCS & Jul. 2007 & ORI-837 & 31 & $6.10-8.14$ & $6.91 \pm 0.42$ \\
\hline \multirow[t]{3}{*}{ WPS } & along $22^{\circ} \mathrm{N}$ from $121^{\circ} \mathrm{E}$ to $126^{\circ} \mathrm{E}$ & Aug. 2004 & ORI-725 & 24 & $3.82-5.52$ & $4.65 \pm 0.39$ \\
\hline & along $22^{\circ} \mathrm{N}$ from $121^{\circ} \mathrm{E}$ to $124^{\circ} \mathrm{E}$ & May. 2006 & ORIII-1149 & 11 & $3.19-5.84$ & $4.70 \pm 0.98$ \\
\hline & $\begin{array}{l}\text { From northeastern coast of Taiwan to } \\
\text { the Luzon Strait (surface water only) }\end{array}$ & Jul. 2007 & ORI-837 & 9 & $6.22-8.19$ & $7.31 \pm 0.71$ \\
\hline
\end{tabular}

(Hawaii, United States station) in the years 2003-2007 were 318.26 ppbv, 318.96 ppbv, 319.75 ppbv, 320.48 ppbv, and 321.35 ppbv, respectively.

Saturation, expressed in \%, was calculated using $R=\left(C_{o b s} / C_{e q}\right)^{*}$ 100 where $C_{o b s}$ represents the observed concentration of the gas that was dissolved in the water, and $C_{e q}$ is the expected equilibrium water concentration, computed using the Henry's Law.

\subsection{Excess $\mathrm{N}_{2} \mathrm{O}\left(\Delta \mathrm{N}_{2} \mathrm{O}\right)$}

The excess $\mathrm{N}_{2} \mathrm{O}\left(\Delta \mathrm{N}_{2} \mathrm{O}\right)$ concentration was calculated as the difference between the calculated $\mathrm{N}_{2} \mathrm{O}$ equilibrium concentration and the observed $\mathrm{N}_{2} \mathrm{O}$ concentration as follows:

$\Delta \mathrm{N}_{2} \mathrm{O}\left(\right.$ nmolL $\left.^{-1}\right)=\mathrm{N}_{2} \mathrm{O}$ ( observed $)-\mathrm{N}_{2} \mathrm{O}$ (equilibrium) .

To calculate the $\mathrm{N}_{2} \mathrm{O}$ equilibrium concentration, different atmospheric mole fractions were used for different water layers. Between the mixed layer and the atmosphere, $\mathrm{N}_{2} \mathrm{O}$ exchanges occurred within three weeks or so (Najjar, 1992); thus, we calculated $\mathrm{N}_{2} \mathrm{O}$ in the mixed layer using the actual atmospheric $\mathrm{N}_{2} \mathrm{O}$ value. That is, the $\Delta \mathrm{N}_{2} \mathrm{O}$ in the surface water layer $(0-350 \mathrm{~m})$ was calculated using the actual atmospheric $\mathrm{N}_{2} \mathrm{O}$ concentration of 318-321 ppb for 20032007. Below the thermocline, in the absence of exchange with the atmosphere, the calculated $\mathrm{N}_{2} \mathrm{O}$ equilibrium concentrations depend on the atmospheric $\mathrm{N}_{2} \mathrm{O}$ mole fraction at the time of deep-water formation. However, the exact atmospheric mole fraction of $\mathrm{N}_{2} \mathrm{O}$ during deep-water formation is unknown because of uncertainty in the determined age of water masses (Walter et al., 2006). According to England (1995) modeling data, the intermediate water (755 m) and the deep water $(1622 \mathrm{~m})$ in the western North Pacific Ocean are approximately 500 and 900 years old. The radiocarbon observations that were made by Gebbie and Huybers (2012) indicated that the Pacific Deep Water (PDW) is $1200-1500$ years old. Therefore, $\Delta \mathrm{N}_{2} \mathrm{O}$ in the intermediate water layer $(350-1350 \mathrm{~m})$ and the deep water layer $(1350-2200 \mathrm{~m})$ of the WPS was calculated using the tropospheric preindustrial value of $270 \mathrm{ppb}$ (Fluckiger, et al., 1999); for depths $>2200 \mathrm{~m}$, an atmospheric value of $260 \mathrm{ppb}$ (MacFarling Meure et al., 2006) was used.

Chen and Huang (1995), Chen et al. (2015) reported that waters in the SCS exchange rapidly and horizontally with the WPS so the intermediate and deep waters are essentially of the same age as corresponding waters in the WPS. The deep WPS water at around $2200 \mathrm{~m}$ flows across the deep sill (Chen et al., 2001) into the SCS and has become the deep water and the bottom water of the SCS (Nitani, 1972; Liu and Liu, 1988; Chen et al., 2001). Therefore, the waters at around $2200 \mathrm{~m}$ and deeper in the SCS are of similar age as the water at $2200 \mathrm{~m}$ in the WPS. Consequently, an atmospheric value of $270 \mathrm{ppb}$ was used to calculate the $\Delta \mathrm{N}_{2} \mathrm{O}$ for the water depth greater than $350 \mathrm{~m}$ in the SCS.

\subsection{Fluxes}

Fluxes of $\mathrm{N}_{2} \mathrm{O}$ across the air-water interface were estimated using $F=k\left(C_{w}-\beta C_{a}\right)$ where $C_{w}$ represents the concentration of dissolved gas in the water $\left(\mathrm{mol} \mathrm{L}^{-1}\right) ; \beta$ is the Bunsen solubility, $C_{a}$ is the atmospheric gas concentration, and $k\left(\mathrm{~cm} \mathrm{~h}^{-1}\right)$ is the gas exchange coefficient. The value of $k$ is a specific function of the property of the gas, the temperature $\mathrm{T}\left({ }^{\circ} \mathrm{C}\right)$ and the wind speed $u$ $\left(\mathrm{m} \mathrm{s}^{-1}\right)$. In the previous research, $k$ has commonly been calculated using the linear $\mathrm{k} /$ wind speed relationship that was established by Liss and Merlivat (1986) (LM86) or the quadratic k/wind speed relationship that was established by Wanninkhof, (1992) (W92). Wanninkhof, (2014) updated the frequently used method of Wanninkhof, (1992), and a new $k$ was calculated. The updated relationship is given by $k=0.251 u^{2}(\mathrm{Sc} / 660)^{-0.5}$, where $k$ is the gas transfer velocity; $u$ is the mean wind speed, and Sc is the Schmidt number, which is the kinematic viscosity of water divided by the molecular diffusion coefficient of the gas. A positive flux indicates the gas transfer from the water to the atmosphere.

Wind speeds at $10 \mathrm{~m}$ above the surface were obtained from the National Aeronautics and Space Administration (NASA) QuikSCAT satellite platform (https://winds.jpl.nasa.gov/missions/quikscat/). The average monthly wind speed was used to estimate the sea-toair flux. The seawater fluxes from the SCS to the WPS were taken from Chen et al. (2001). The principle of conservation of water masses requires that the flow of water into the SCS be balanced by the outflow of water.

\section{Results and discussion}

\subsection{West Philippines Sea}

The average surface $\mathrm{N}_{2} \mathrm{O}$ concentration in the WPS in the wet season was $5.19 \pm 1.26 \mathrm{nmol} \mathrm{L}^{-1}(90 \pm 22 \%$ saturation; $\mathrm{n}=43)$. In the WPS, the $\mathrm{N}_{2} \mathrm{O}$ (Fig. 2a) concentration gradually increased with the depth up to $1000 \mathrm{~m}$, reaching a maximum of approximately $23 \mathrm{nmol} \mathrm{L}^{-1}$ at $800-1000 \mathrm{~m}$, coinciding with a DO minimum (Fig. 2b). The $\mathrm{N}_{2} \mathrm{O}$ concentration gradually decreased with depth beyond $1000 \mathrm{~m}$ because seawater at depths of greater than $1000 \mathrm{~m}$ in the WPS reflects the $\mathrm{N}_{2} \mathrm{O}$ distribution of the Pacific Deep Water (PDW), which has a low $\mathrm{N}_{2} \mathrm{O}$ concentration. According to Usui et al. (1998), Bange and Andreae (1999), the $\mathrm{N}_{2} \mathrm{O}$ concentration at depths of $3000-5000 \mathrm{~m}$ in the North Pacific is only around $17.5-22 \mathrm{nmol} \mathrm{L}^{-1}$.

\subsection{South China Sea}

The surface $\mathrm{N}_{2} \mathrm{O}$ concentration in the wet season in the SCS was $7.59 \pm 1.32 \mathrm{nmol} \mathrm{L}^{-1}(132 \pm 23 \%$ saturation; $\mathrm{n}=105)$. The $\mathrm{N}_{2} \mathrm{O}$ 
(a)

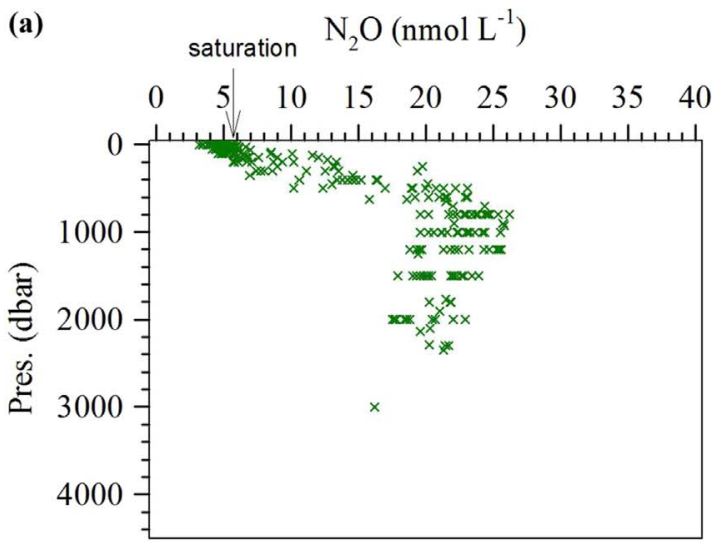

(b)

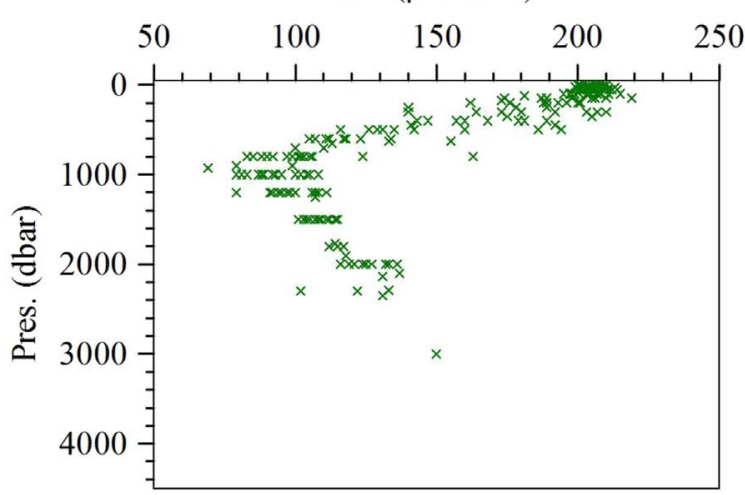

(c)

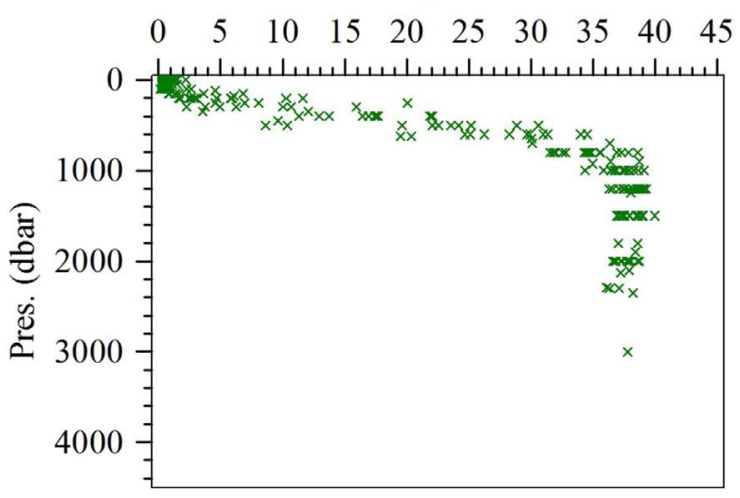

(d)

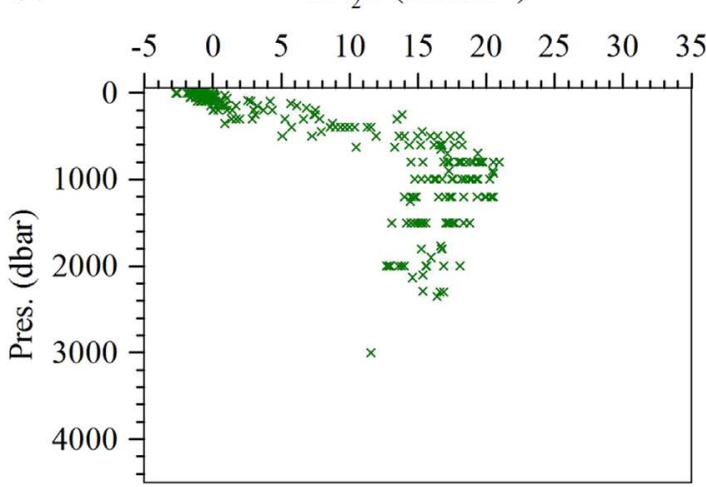

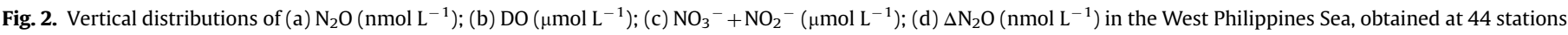
during three cruises between August 2004 and July 2007.

concentration in the water column of the SCS notably exceeds that in the WPS, and the SCS has a shallower $\mathrm{N}_{2} \mathrm{O}$ maximum (Fig. 3a) at approximately $600-800 \mathrm{~m}$ compared with the $800-1000 \mathrm{~m}$ in the WPS. This is due to the upwelling in the SCS. In both the SCS and the WPS, the $\mathrm{N}_{2} \mathrm{O}$ maxima (Figs. 2a and 3a) are at the depths where DO is at a minimum (Figs. 2b and 3b). The surface and intermediate waters are exchanged freely between the SCS and the WPS, and the deep water below $1350 \mathrm{~m}$ flows into the SCS from the WPS (Chen et al., 2001). However, waters at depths of greater than $2200 \mathrm{~m}$ in the WPS, including the Pacific Deep Water and the Antarctic Bottom Water, cannot enter the SCS (Chen et al., 2001, 2006). The intermediate and deep SCS waters above $2200 \mathrm{~m}$ mix with the WPS water, which has a lower $\mathrm{N}_{2} \mathrm{O}$ concentration, so the $\mathrm{N}_{2} \mathrm{O}$ concentration gradually decreases with increasing depth beyond the $\mathrm{N}_{2} \mathrm{O}$ maximum but remains constant at depths in excess of $2200 \mathrm{~m}$.

In the SCS, some sampling stations close to the continental slope have high $\mathrm{N}_{2} \mathrm{O}$ concentrations $\left(\mathrm{N}_{2} \mathrm{O}>32 \mathrm{nmol} \mathrm{L}^{-1}\right.$; Fig. 3a) at around $400-1000 \mathrm{~m}$. Fig. 4 shows the cross-section in the northeastern SCS in 2003 (ORIII-896) and Fig. 5 presents the crosssection between the eastern and the southern SCS in 2007 (ORI837). The water column of the sections were well stratified in both temperature and salinity in the summer (Figs. 4a, b, 5a, and b). The DO concentrations decreased from the surface layer to the DO minima (Figs. $4 \mathrm{c}$ and $5 \mathrm{c}$ ) while $\mathrm{N}_{2} \mathrm{O}$ concentrations increased with the depth to the $\mathrm{N}_{2} \mathrm{O}$ maxima at approximately $600-800 \mathrm{~m}$ (Figs. $4 \mathrm{~d}$ and $5 \mathrm{~d}$ ). Figs. $4 \mathrm{~d}$ and $5 \mathrm{~d}$ show that sampling stations close to the continental slope have high $\mathrm{N}_{2} \mathrm{O}$ concentrations at around 400-1000 m. Similarly, Zhang et al. (2008) measured high concentrations of $\mathrm{N}_{2} \mathrm{O}$ in the bottom waters of the continental slope in the East China Sea, which may have been related to the production and emission of $\mathrm{N}_{2} \mathrm{O}$ from the organic-rich sediments or re-suspended particles (Zhu et al., 2006). Lin et al. (1992) found a layer with a high particle concentration immediately above the sediments on the continental slope, probably as a result of the crossshelf transport. Walsh et al. (1985) suggested that lateral particle transport in the water column has an important role in determining the final fate for the organic particle. Therefore, these high $\mathrm{N}_{2} \mathrm{O}$ concentrations are assumed herein to have been produced from organic particles on the continental slope close to the sampling stations. High $\mathrm{CH}_{4}$ concentrations were also observed at the sampling stations close to the continental slope (Tseng et al., submitted).

\subsection{Comparison of $\mathrm{N}_{2} \mathrm{O}$ distributions in the SCS and WPS}

The average surface $\mathrm{N}_{2} \mathrm{O}$ concentration during the wet season in the SCS was about 30\% higher than that in the WPS. There are many rivers flowing into the SCS, which discharge not only rich nutrients but also high concentrations of $\mathrm{N}_{2} \mathrm{O}$ (Chen et al., 2008). Fig. 6 presents the surface distribution of salinity and $\mathrm{N}_{2} \mathrm{O}$ near the Pearl River estuary in 2003. Higher $\mathrm{N}_{2} \mathrm{O}$ concentrations with lower salinities occurred near the estuaries (Fig. 6). This result indicates that the high surface $\mathrm{N}_{2} \mathrm{O}$ concentrations near the Pearl River estuary was caused by fresh water inputs. Additionally, upwelling often occurs in the SCS (Zheng and Tang, 2007; Han et al., 2013), bringing nutrients and high concentrations of $\mathrm{N}_{2} \mathrm{O}$ from greater depths to the surface waters. Furthermore, increasing nutrient contents and subsequent phytoplankton blooms (Zheng and Tang, 2007; Herbeck et al., 2011) may also influence the production and emission of $\mathrm{N}_{2} \mathrm{O}$ (Naik et al., 2008; Walker et al., 2010) in the SCS.

Figs. $2 \mathrm{c}$ and $3 \mathrm{c}$ show the distributions of $\mathrm{NO}_{3}{ }^{-}+\mathrm{NO}_{2}{ }^{-}$in the 
(a)

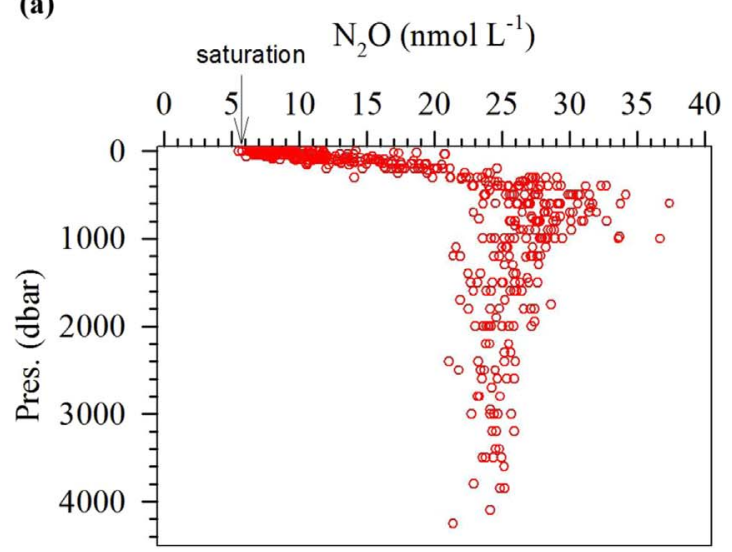

(b)

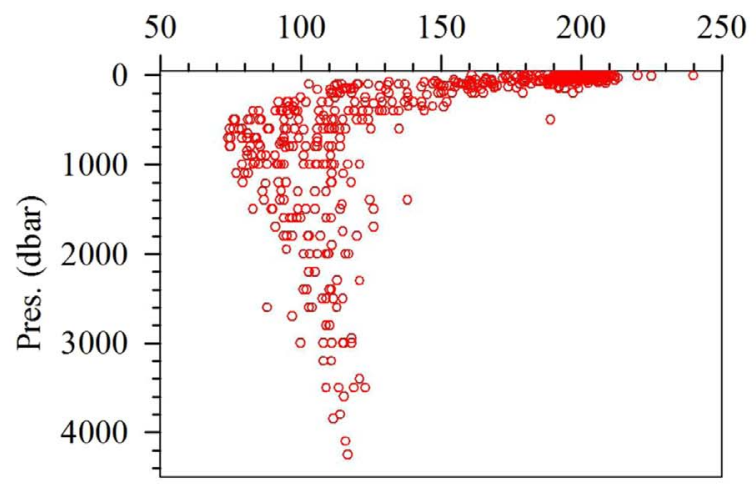

(c)

$\mathrm{NO}_{3}^{-}+\mathrm{NO}_{2}^{-}\left(\mu \mathrm{mol} \mathrm{L}{ }^{-1}\right)$

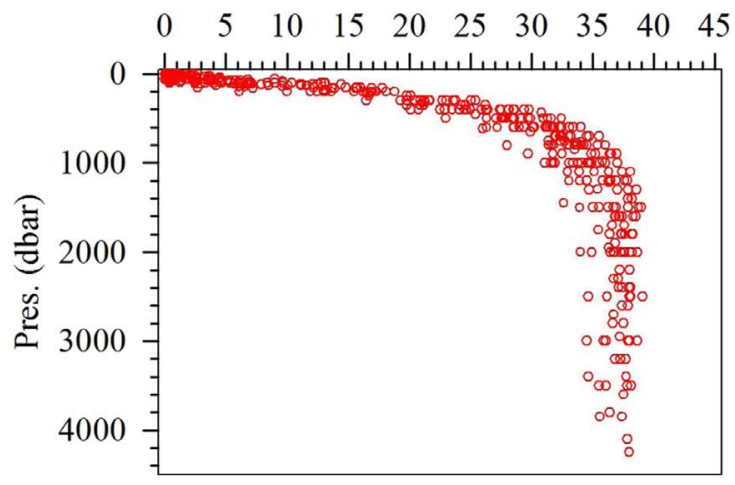

(d)

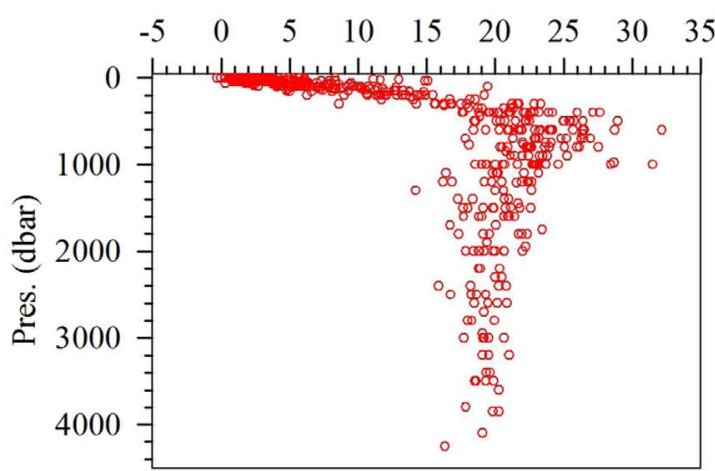

Fig. 3. Vertical distributions of (a) $\mathrm{N}_{2} \mathrm{O}\left(\mathrm{nmol} \mathrm{L}{ }^{-1}\right)$; (b) $\mathrm{DO}\left(\mu \mathrm{mol} \mathrm{L}^{-1}\right)$; (c) $\mathrm{NO}_{3}{ }^{-}+\mathrm{NO}_{2}{ }^{-}$( $\mu$ mol L $\left.{ }^{-1}\right)$; (d) $\Delta \mathrm{N}_{2} \mathrm{O}\left(\mathrm{nmol} \mathrm{L}^{-1}\right.$ ) in the South China Sea, obtained at 106 stations during five cruises between August 2003 and July 2007.

WPS and in the SCS, respectively. The $\mathrm{NO}_{3}{ }^{-}+\mathrm{NO}_{2}{ }^{-}$concentration at depths of less than $600 \mathrm{~m}$ in the SCS exceeds that in the WPS for two reasons. First, many rivers that are rich in $\mathrm{NO}_{3}{ }^{-}$and $\mathrm{NO}_{2}{ }^{-}$ flow into the SCS. In particular, two of the largest rivers in the world (the Mekong and Pearl Rivers) enter from the north, contributing large amounts of nutrients and organic matter to the SCS, especially in the wet season (Yin et al., 2000; Chen et al., 2008). Also, the high-nutrient riverine water fuels higher productivity in the SCS relative to the WPS. Fig. 7 shows that the chlorophyll $a$ concentrations in the surface and subsurface waters of the SCS are much higher than in the WPS, which reflects the higher productivity in the SCS.

Second, the deep WPS water flows across the deep sill ( $2200 \mathrm{~m}$; Chen et al., 2001) into the SCS. This deep WPS water at around $2200 \mathrm{~m}$ becomes the deep water and the bottom water of the SCS (Nitani, 1972; Liu and Liu, 1988; Chen et al., 2001). The $\mathrm{NO}_{3}{ }^{-}+\mathrm{NO}_{2}{ }^{-}$accumulates in the SCS, because of the flow pattern. This effect, together with the vertical mixing and upwelling, brings $\mathrm{NO}_{3}{ }^{-}+\mathrm{NO}_{2}{ }^{-}$to the upper water, causing the concentration of $\mathrm{NO}_{3}{ }^{-}+\mathrm{NO}_{2}{ }^{-}$in the SCS to be higher than that in the WPS at depths of less than $600 \mathrm{~m}$, but lower at depths of greater than $600 \mathrm{~m}$.

The vertical profiles of $\mathrm{N}_{2} \mathrm{O}$ and $\mathrm{DO}$ and, in particular, the coinciding $\mathrm{N}_{2} \mathrm{O}$ maxima and DO minima (at 800-1000 $\mathrm{m}$ in the WPS and $600-800 \mathrm{~m}$ in the SCS), reveal that nitrification dominates the $\mathrm{N}_{2} \mathrm{O}$ production, as was also found in previous research (Yoshinari, 1976). In short, the SCS has shallower $\mathrm{N}_{2} \mathrm{O}$ maxima and DO minima than the WPS because of the intensive upwelling.

\subsection{In situ biological production}

Most studies in the field have used the contemporary atmospheric $\mathrm{N}_{2} \mathrm{O}$ mole fraction, which is independent of the "real" age of the sampled water masses for the calculation of $\Delta \mathrm{N}_{2} \mathrm{O}$. This approach is highly suitable for calculating $\Delta \mathrm{N}_{2} \mathrm{O}$ in waters in surface layers, but neglects the effect of the age of the water mass and, therefore, the variable atmospheric mole fraction that is involved in establishing an initial "equilibrium" (Walter et al., 2006; Freing et al., 2009). Nevison et al. (2003) asserted that the use of only the contemporary atmospheric mole fraction introduces an uncertainty of $10-15 \%$ in the estimate of $\Delta \mathrm{N}_{2} \mathrm{O}$. Walter et al., (2006) showed that using "the contemporary atmospheric mole fraction" instead of "the initial atmospheric mole fraction" yielded a $7 \%$ smaller $\Delta \mathrm{N}_{2} \mathrm{O}$ at depths of less than $2000 \mathrm{~m}$, and a $17 \%$ smaller $\Delta \mathrm{N}_{2} \mathrm{O}$ at depths of greater than $2000 \mathrm{~m}$ in the North Atlantic Ocean. This $\Delta \mathrm{N}_{2} \mathrm{O}$ difference at a particular depth may be higher in the Pacific Ocean than in the Atlantic Ocean because the deep water masses in the Pacific Ocean are older (England, 1995; Gebbie and Huybers, 2012). Fig. 8 presents the effect of depthdependent initial atmospheric mole fractions on the $\Delta \mathrm{N}_{2} \mathrm{O}$. There is no difference between the results above $350 \mathrm{~m}$ because the initial atmospheric mole fraction is taken to be equal to the contemporary atmospheric mole fraction. On the other hand, the equilibrium concentration of $\mathrm{N}_{2} \mathrm{O}$ below $350 \mathrm{~m}$ that is calculated using the method herein, is generally lower than those obtained using a uniform $\mathrm{N}_{2} \mathrm{O}$ mole fraction because "the initial atmospheric $\mathrm{N}_{2} \mathrm{O}$ mole fraction" is lower than "the contemporary atmospheric $\mathrm{N}_{2} \mathrm{O}$ mole fraction." Thus, the $\Delta \mathrm{N}_{2} \mathrm{O}$ may be underestimated by using a uniform atmospheric $\mathrm{N}_{2} \mathrm{O}$ mole fraction. Therefore, we calculated the $\Delta \mathrm{N}_{2} \mathrm{O}$ herein by using different atmospheric $\mathrm{N}_{2} \mathrm{O}$ 


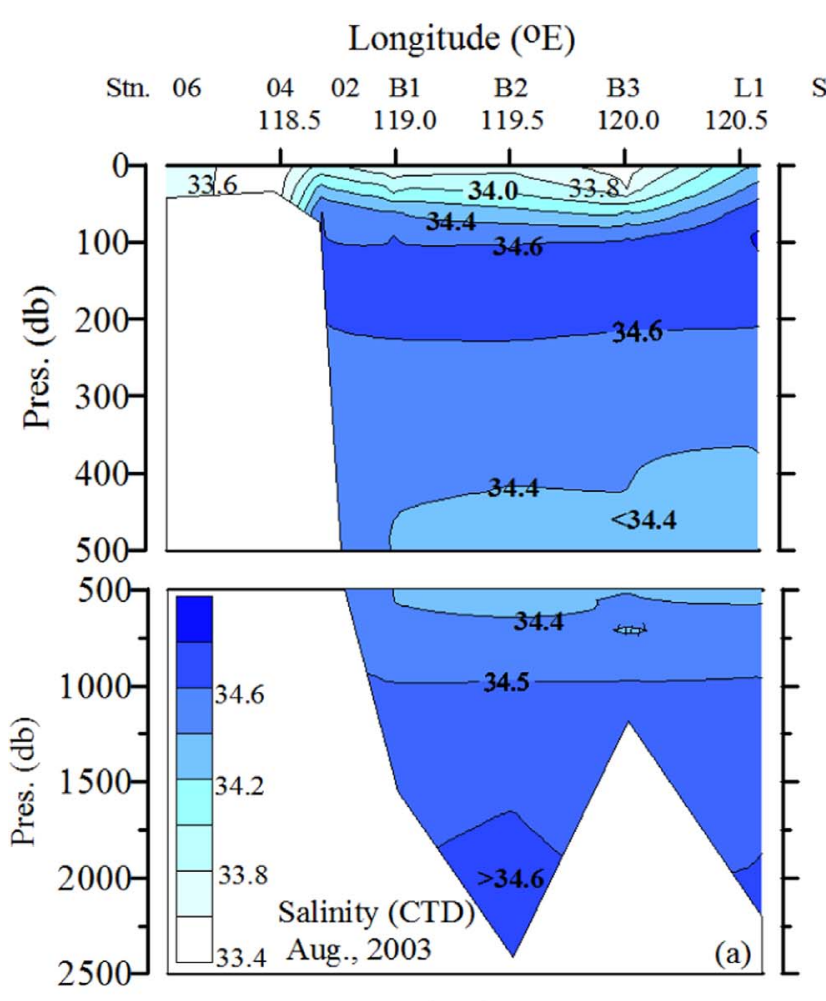

\begin{tabular}{ccccccc}
\multicolumn{1}{c}{ Longitude (OE) } \\
tn. 06 & 04 & 02 & $\mathrm{~B} 1$ & $\mathrm{~B} 2$ & $\mathrm{~B} 3$ & $\mathrm{~L} 1$
\end{tabular}
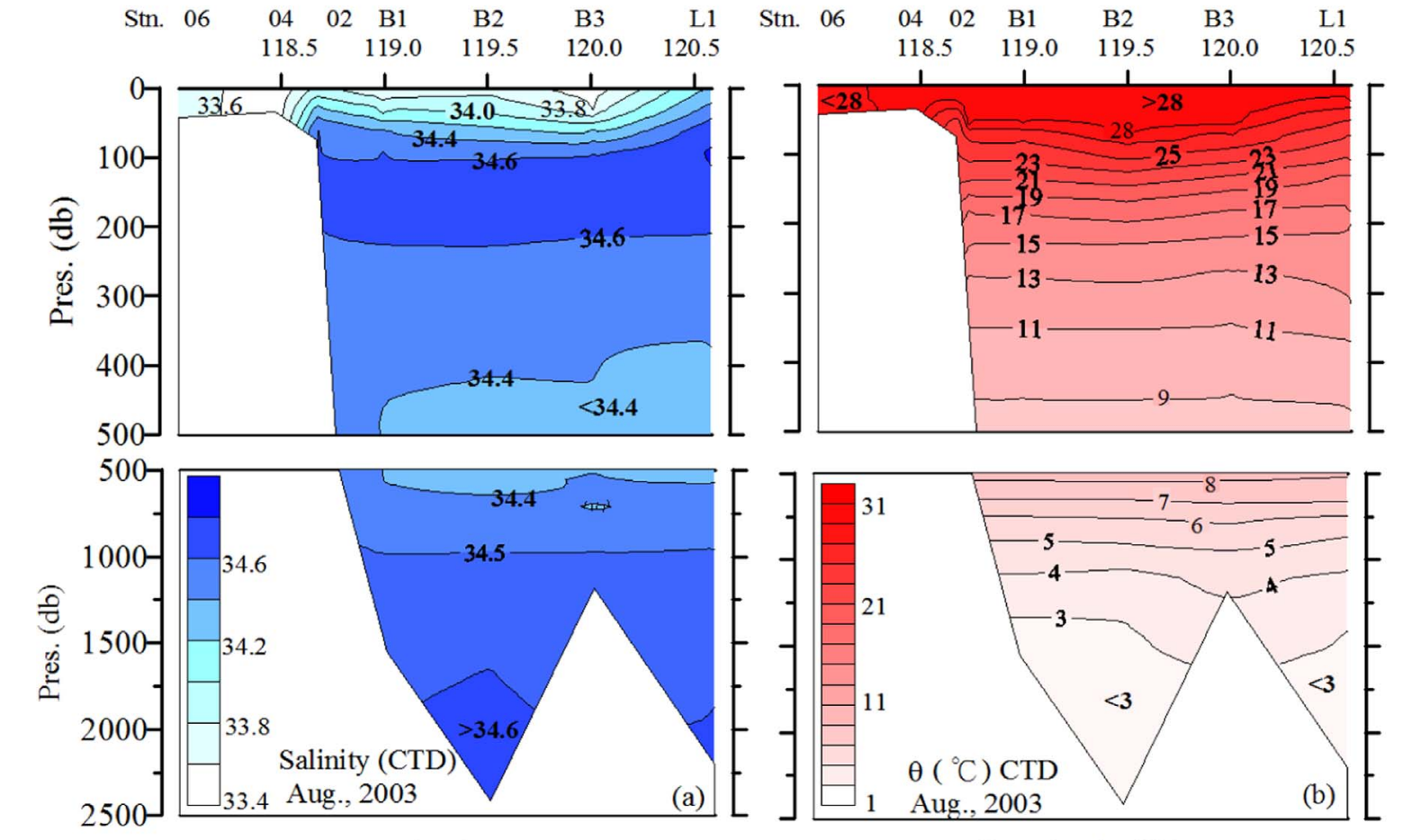

Longitude ( $\left.{ }^{\mathrm{O}} \mathrm{E}\right)$

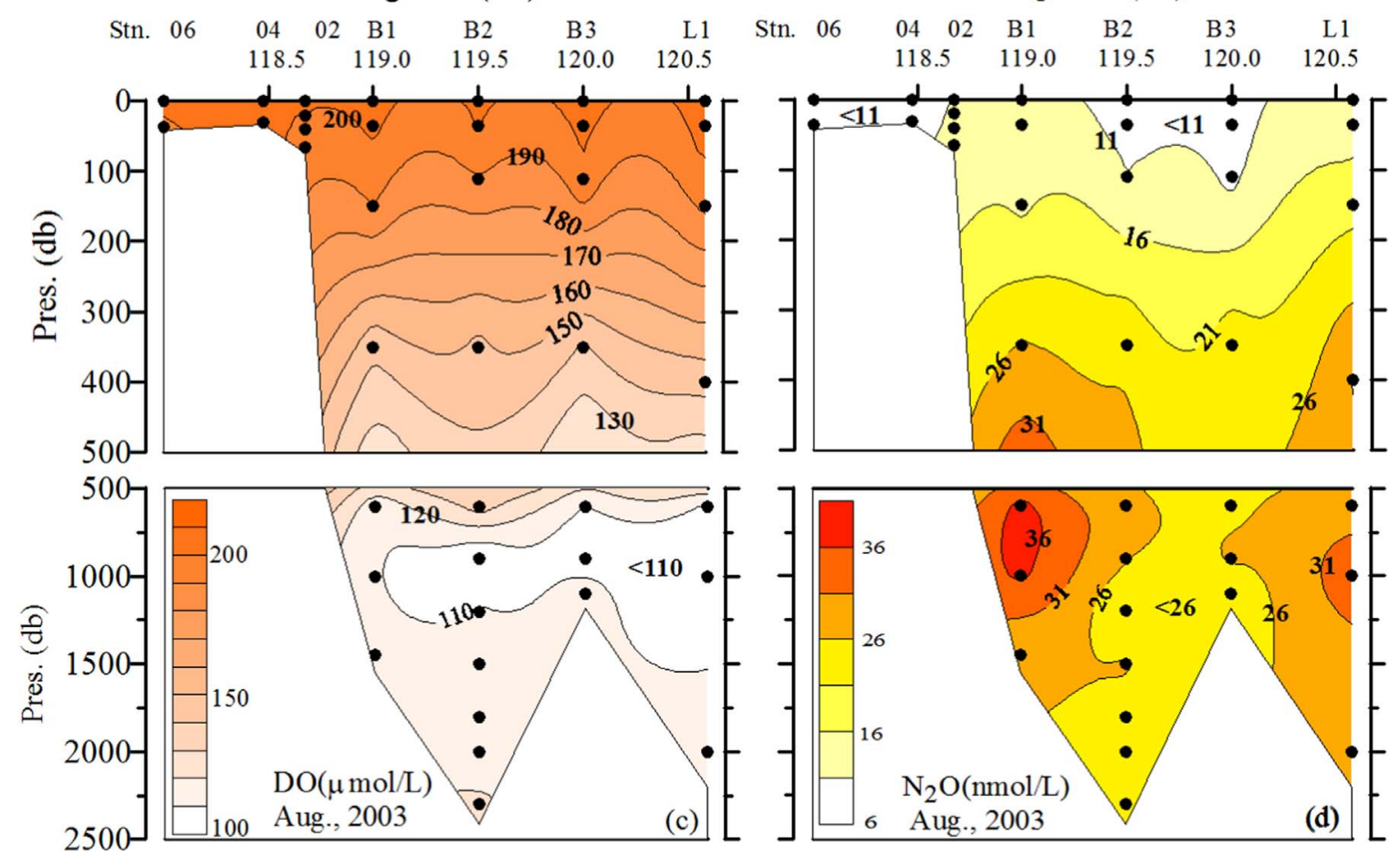

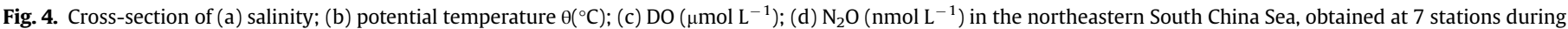
ORIII-896 cruise in August 2003.

mole fractions for different water layers to reduce the uncertainty of the $\Delta \mathrm{N}_{2} \mathrm{O}$. Note there is a discontinuity in the percentage deviation of $\Delta \mathrm{N}_{2} \mathrm{O}$ at $350 \mathrm{~m}$. This is caused by the sudden change of the initial atmospheric mole fraction from 318 to $321 \mathrm{ppb}$ for waters above $350 \mathrm{~m}$ to $270 \mathrm{ppb}$ for waters below $350 \mathrm{~m}$. This artifact cannot yet be resolved without the knowledge of the exact age and the corresponding atmospheric $\mathrm{N}_{2} \mathrm{O}$ concentration for subsurface water masses.
The $\Delta \mathrm{N}_{2} \mathrm{O}$ deviations at around $400-600 \mathrm{~m}$ in the WPS are rather large, because waters there have lower $\mathrm{N}_{2} \mathrm{O}$ concentrations compared with that in the deeper water. To calculate $\Delta \mathrm{N}_{2} \mathrm{O}$ by using "the contemporary atmospheric mole fraction" instead of "the initial atmospheric mole fraction" may cause an error as high as $19 \%$ of the $\Delta \mathrm{N}_{2} \mathrm{O}$ deviation, especially in the area which has low $\mathrm{N}_{2} \mathrm{O}$ concentrations. The mean $\Delta \mathrm{N}_{2} \mathrm{O}$ deviation below the surface layer is about $-6.1 \pm 2.0 \%(n=131)$ in the WPS and $-4.1 \pm 0.5 \%$ 
Longitude (OE)

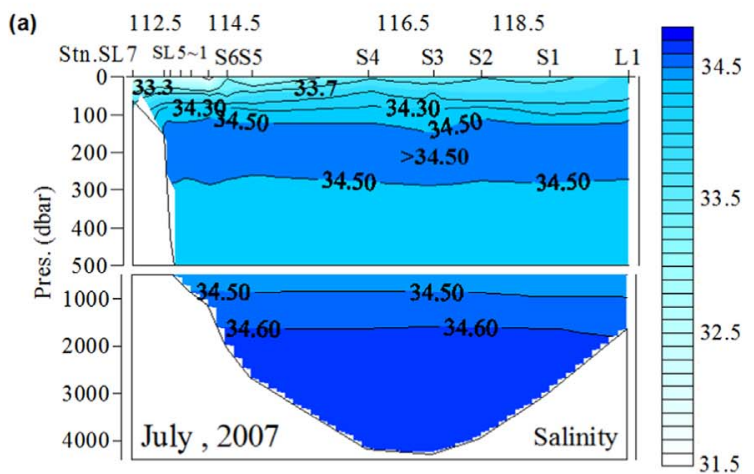

(b)

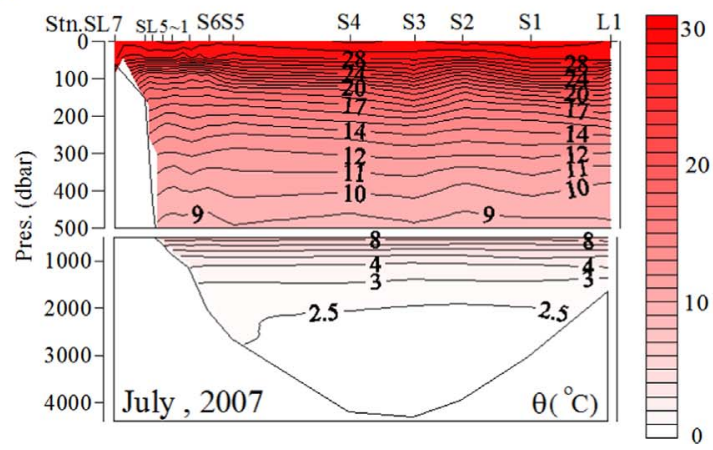

Longitude $(\mathrm{O} E)$

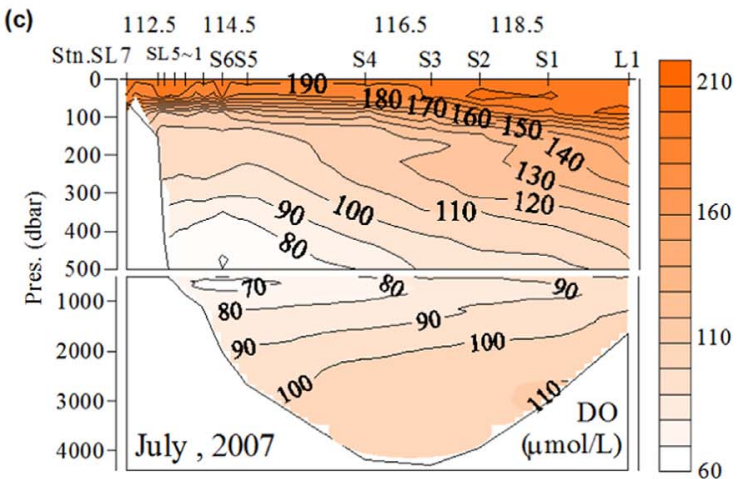

(d)

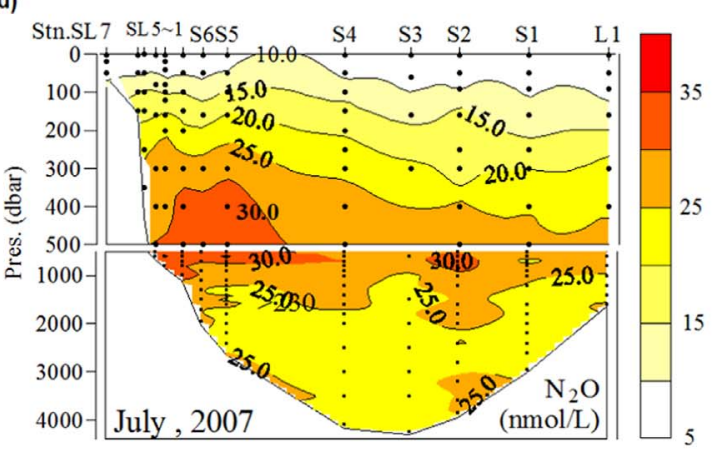

Fig. 5. Cross-section of (a) salinity; (b) potential temperature $\theta\left({ }^{\circ} \mathrm{C}\right)$; (c) DO $\left(\mu \mathrm{mol} \mathrm{L}^{-1}\right)$; (d) $\mathrm{N}_{2} \mathrm{O}\left(\mathrm{nmol} \mathrm{L}^{-1}\right)$ between the eastern and southern South China Sea, obtained at 13 stations during ORI-837 cruise in July 2007.

$(\mathrm{n}=234)$ in the SCS.

Several investigations have reported linear relationships between $\Delta \mathrm{N}_{2} \mathrm{O}$ and AOU in various oceanic areas (Yoshinari, 1976; Elkins et al., 1978; Cohen and Gordon, 1979; Butler et al., 1989; Law and Owens, 1990; Oudot et al., 1990; Naqvi and Noronha, 1991; Naqvi et al., 1994; Nevison et al., 1995, 2003). The AOU quantifies the amount of $\mathrm{O}_{2}$ that is consumed by the remineralization of organic matter and nitrification in a water parcel since its last contact with the atmosphere. A strong correlation between AOU and $\Delta \mathrm{N}_{2} \mathrm{O}$ in the oceans is frequently observed, providing circumstantial evidence that nitrification is the dominant mechanism of oceanic $\mathrm{N}_{2} \mathrm{O}$ production (Yoshinari, 1976; Elkins et al., 1978; Cohen and Gordon, 1979; Butler et al., 1989; Patra et al., 1999; Nevison et al., 2003).
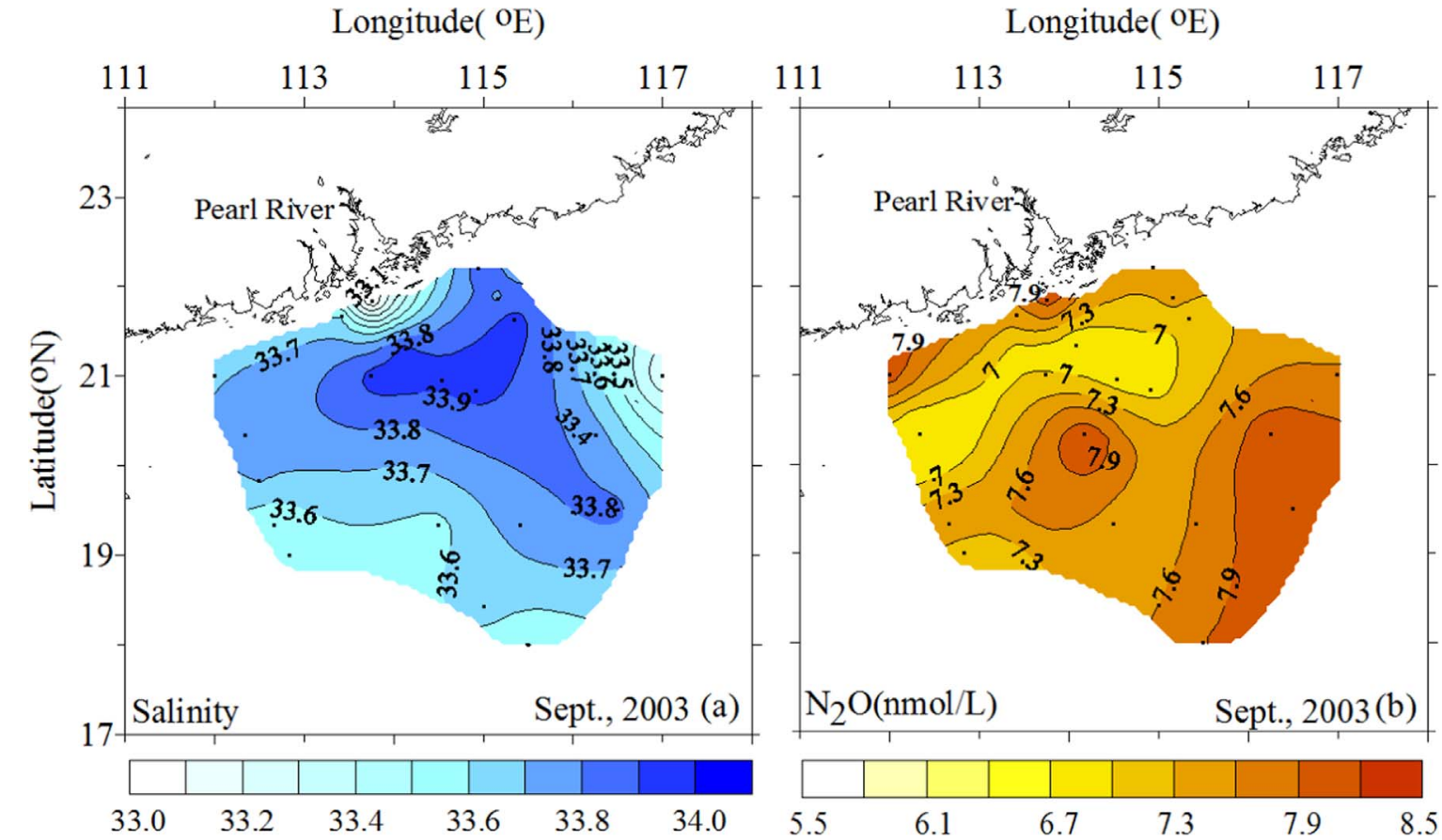

Fig. 6. Surface distributions of (a) salinity; (b) $\mathrm{N}_{2} \mathrm{O}\left(\mathrm{nmol} \mathrm{L}^{-1}\right)$ near the Pearl River estuary, obtained at 22 stations during ORI-695 cruise in September 2003. 


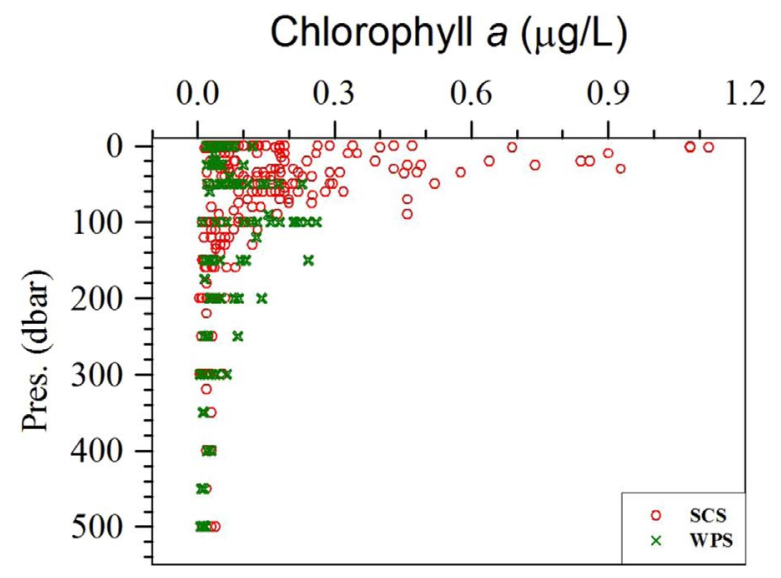

Fig. 7. Vertical distributions of chlorophyll $a$ in the South China Sea and the West Philippines Sea above depth of $500 \mathrm{~m}$, obtained at 91 stations during six cruises between August 2003 and July 2007.

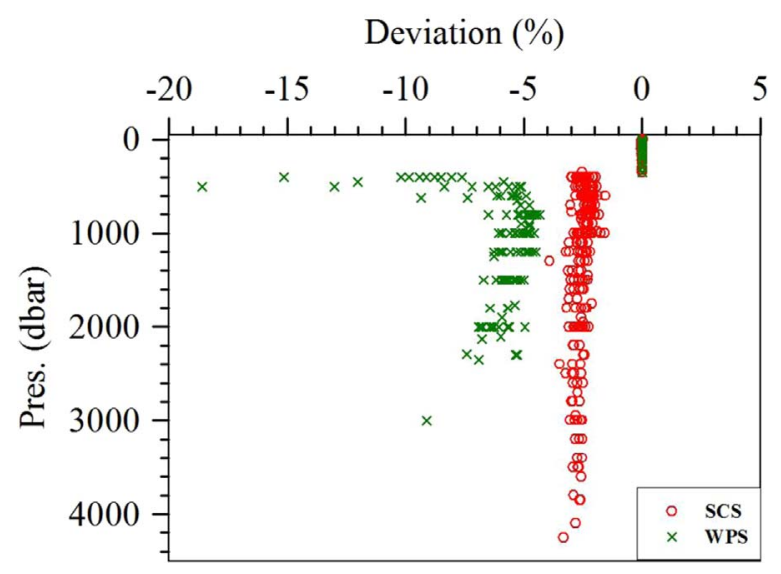

Fig. 8. The percentage deviation of $\Delta \mathrm{N}_{2} \mathrm{O}$, between $\mathrm{N}_{2} \mathrm{O}$ equilibrium concentration calculated using a uniform mole fraction of 318-321 ppb for years 2003-2007 and depth-dependent $\mathrm{N}_{2} \mathrm{O}$ equilibrium concentration calculated using mole fractions of 318-321 ppb, $270 \mathrm{ppb}$ and $260 \mathrm{ppb}$ for the West Philippines Sea and mole fractions of 318-321 ppb and $270 \mathrm{ppb}$ for the South China Sea.

Fig. 9 reveals that at depths of less than that of the maximum $\mathrm{N}_{2} \mathrm{O}$ concentrations ( $\mathrm{AOU}<200 \mu \mathrm{mol} \mathrm{kg}^{-1}$ ), $\Delta \mathrm{N}_{2} \mathrm{O}$ is positively correlated with $\mathrm{AOU}$ and $\mathrm{NO}_{3}{ }^{-}$in both the WPS and the SCS, implying that $\mathrm{N}_{2} \mathrm{O}$ is produced mainly through biological processes. However, at depths that exceed that of the maximum $\mathrm{N}_{2} \mathrm{O}$ concentration, $\Delta \mathrm{N}_{2} \mathrm{O}$ and $\mathrm{AOU}$ seem to be uncorrelated. In fact, $\Delta \mathrm{N}_{2} \mathrm{O}$ and $\mathrm{NO}_{3}{ }^{-}$even seem to be negatively correlated.

The relationships between $\Delta \mathrm{N}_{2} \mathrm{O}$ and AOU and between $\Delta \mathrm{N}_{2} \mathrm{O}$ and $\mathrm{NO}_{3}{ }^{-}$are studied to provide further insight into the biological production of $\mathrm{N}_{2} \mathrm{O}$. Horrigan et al. (1981) indicated that the production of $\mathrm{N}_{2} \mathrm{O}$ is insignificant in the euphotic zone (from the surface to a depth of 15-100 m), where denitrifiers are inhibited by high oxygen concentrations and nitrifiers are inhibited by light and low $\mathrm{NH}_{4}{ }^{+}$availability. To exclude the effects of sea-air exchange and photo-inhibition, the correlations between $\Delta \mathrm{N}_{2} \mathrm{O}$ and AOU (Fig. 10a) and between $\Delta \mathrm{N}_{2} \mathrm{O}$ and $\mathrm{NO}_{3}{ }^{-}$(Fig. 10b) from the lower euphotic zones (around $100 \mathrm{~m}$ ) to the depth of the maximum $\mathrm{N}_{2} \mathrm{O}$ concentration were examined. The $\Delta \mathrm{N}_{2} \mathrm{O}$ correlates positively with AOU (WPS: $\Delta \mathrm{N}_{2} \mathrm{O}=0.091 \mathrm{AOU}-0.33, \mathrm{n}=111$, $\mathrm{r}^{2}=0.96 ;$ SCS: $\left.\Delta \mathrm{N}_{2} \mathrm{O}=0.121 \mathrm{AOU}+0.17, \mathrm{n}=179, \mathrm{r}^{2}=0.87\right)$ and $\mathrm{NO}_{3}{ }^{-}$(WPS: $\Delta \mathrm{N}_{2} \mathrm{O}=0.53\left[\mathrm{NO}_{3}{ }^{-}\right]+0.60, \mathrm{n}=111, \mathrm{r}^{2}=0.94 ;$ SCS: $\left.\Delta \mathrm{N}_{2} \mathrm{O}=0.70\left[\mathrm{NO}_{3}{ }^{-}\right]+2.86, \mathrm{n}=179, \mathrm{r}^{2}=0.88\right)$, suggesting that nitrification is the major mechanism of the $\mathrm{N}_{2} \mathrm{O}$ production at depths of less than $1000 \mathrm{~m}$ in the WPS and $800 \mathrm{~m}$ in the SCS. The slopes of the linear correlations between $\Delta \mathrm{N}_{2} \mathrm{O}$ and AOU provide
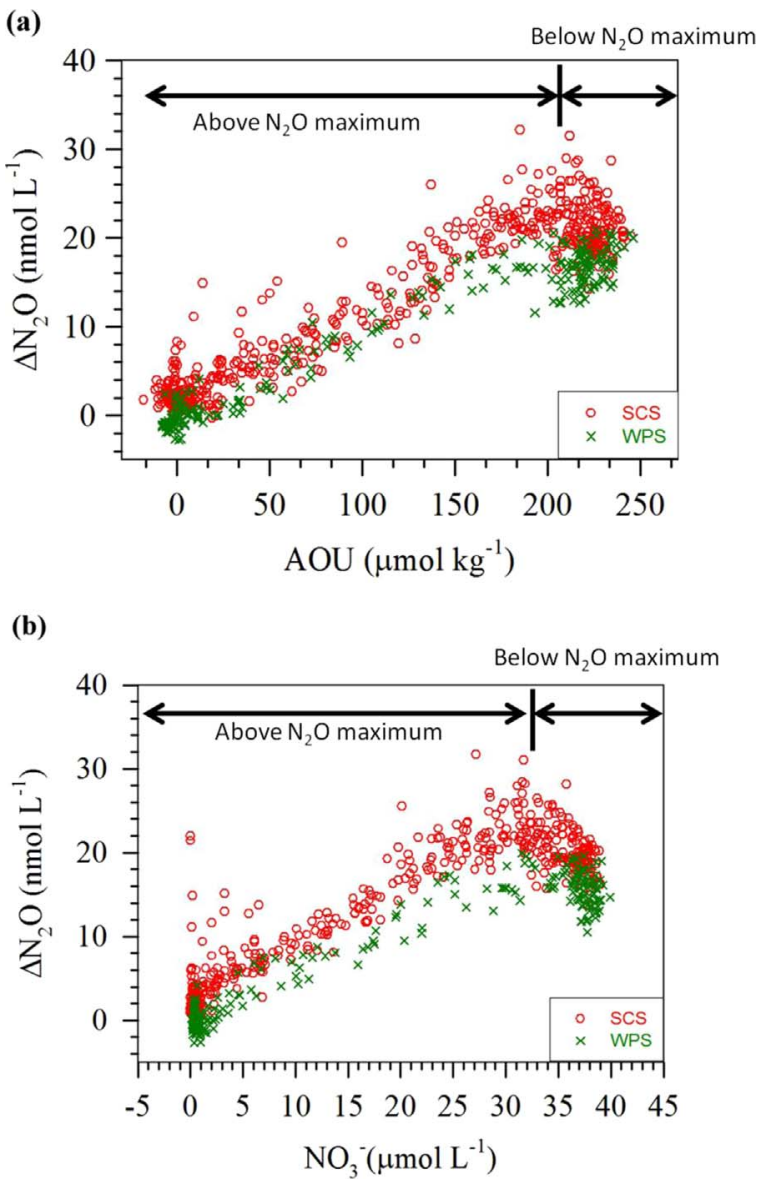

Fig. 9. Comparison of $\Delta \mathrm{N}_{2} \mathrm{O}$ versus (a) $\mathrm{AOU}$ and (b) $\mathrm{NO}_{3}{ }^{-}$concentration in the West Philippines Sea and the South China Sea.

estimates of the amount of $\mathrm{N}_{2} \mathrm{O}$ that is generated per amount of DO consumed (Nevison et al., 2003; Walker et al., 2010). $\mathrm{N}_{2} \mathrm{O}$ yields from nitrification can be estimated from the DO consumption per mole of $\mathrm{N}_{2} \mathrm{O}$ produced (Grundle et al., 2012), following the Redfield stoichiometry (Redfield et al., 1963), which attributes approximately $17.3 \%$ of the total DO consumption to the $\mathrm{NH}_{4}{ }^{+}$ oxidation (Ward, 2008). The correlations of $\Delta \mathrm{N}_{2} \mathrm{O}$ with AOU were utilized herein to reveal that the $\mathrm{N}_{2} \mathrm{O}$ yield from nitrification was $0.053 \pm 0.001 \%$ in the WPS and $0.070 \pm 0.002 \%$ in the SCS between a depth of $100 \mathrm{~m}$ and that of the maximum $\mathrm{N}_{2} \mathrm{O}$ concentration. Strong correlations between $\mathrm{NO}_{3}{ }^{-}$and AOU (Fig. 11c; WPS: $\left[\mathrm{NO}_{3}{ }^{-}\right]=0.168[\mathrm{AOU}]-1.43, \mathrm{n}=111, \mathrm{r}^{2}=0.98 ; \mathrm{SCS}:\left[\mathrm{NO}_{3}{ }^{-}\right]=0.167$ [AOU]-2.81, $\mathrm{n}=179, \mathrm{r}^{2}=0.91$ ) were also found, owing to nitrification in both the WPS and the SCS, as were also found in the western North Pacific (Yoshida et al., 1989). Hence, $\mathrm{N}_{2} \mathrm{O}$ yields of nitrification could be estimated directly from the molar ratio of $\mathrm{N}_{2} \mathrm{O}$ production to $\mathrm{NO}_{3}{ }^{-}$production, which was $0.053 \pm 0.001 \%$ for the WPS and $0.070 \pm 0.002 \%$ for the SCS from a depth of $100 \mathrm{~m}$ to the depth of the maximum $\mathrm{N}_{2} \mathrm{O}$ concentration. These estimates match exactly those estimated from the relationship of $\Delta \mathrm{N}_{2} \mathrm{O}$ versus AOU. This finding supports that most of the $\mathrm{N}_{2} \mathrm{O}$ in the subsurface water in the WPS and the SCS is produced by nitrification.

$\mathrm{N}_{2} \mathrm{O}$ yield from nitrification in the SCS herein slightly exceeded $0.065 \%$ in the shelf region of the SCS (Han et al., 2013), and was also higher than the WPS. $\mathrm{N}_{2} \mathrm{O}$ yields of nitrification in both the SCS and the WPS are higher than those reported elsewhere for the North Pacific Ocean (range, 0.004-0.027\%; Yoshida et al., 1989), the NE subarctic Pacific Ocean (range, 0.028-0.040\%; Grundle et al., 2012), and the subtropical Atlantic Ocean (0.030-0.040\%; Walter 
(a)

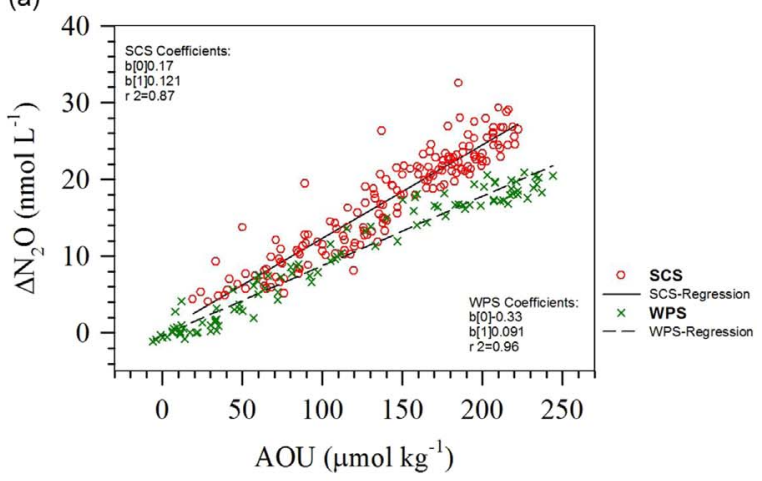

(b)

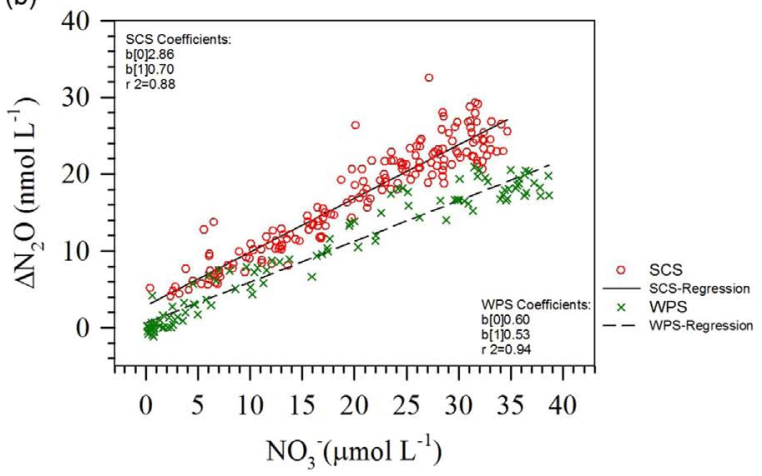

(c)

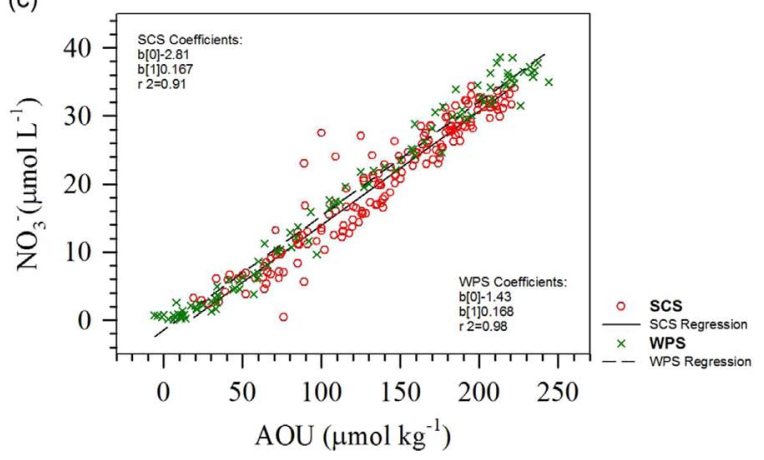

Fig. 10. Relationship between (a) $\Delta \mathrm{N}_{2} \mathrm{O}$ and AOU; (b) $\Delta \mathrm{N}_{2} \mathrm{O}$ and $\mathrm{NO}_{3}{ }^{-}$concentration; (c) $\mathrm{NO}_{3}{ }^{-}$concentration and $\mathrm{AOU}$ at between $100 \mathrm{~m}$ and depth of maximum $\mathrm{N}_{2} \mathrm{O}$ concentration in the West Philippines Sea and the South China Sea.

et al., 2006), but are similar to those obtained for the tropical Atlantic Ocean (0.06-0.08\%; Walter et al., 2006).

At depths greater than that of the maximum $\mathrm{N}_{2} \mathrm{O}$ concentration, the linear relationships between $\Delta \mathrm{N}_{2} \mathrm{O}$ and AOU (Fig. 11a) as well as $\Delta \mathrm{N}_{2} \mathrm{O}$ and $\mathrm{NO}_{3}{ }^{-}$(Fig. 11b) in both the SCS and the WPS are statistically insignificant, presumably owing to changing $\mathrm{N}_{2} \mathrm{O}$ yields and/or physical mixing of different water masses. Fig. 12 shows that the $\Delta \mathrm{N}_{2} \mathrm{O} / \mathrm{AOU}$ ratios decrease with depth but remain constant below $1000 \mathrm{~m}$ both in the SCS and the WPS. Butler et al. (1989) hypothesized that the decline in the $\mathrm{N}_{2} \mathrm{O}$ concentration with depth may reflect the pressure inhibition of the primary nitrification pathway that leads to the $\mathrm{N}_{2} \mathrm{O}$ production. Nevison et al. (2003) and Codispoti (2010) also pointed out that the $\mathrm{N}_{2} \mathrm{O}$ concentration and the $\Delta \mathrm{N}_{2} \mathrm{O} / \mathrm{AOU}$ ratio tend to decrease at high pressure or AOU. The $\Delta \mathrm{N}_{2} \mathrm{O}$ concentrations and $\mathrm{N}_{2} \mathrm{O}$ yields that are presented herein represent the $\mathrm{N}_{2} \mathrm{O}$ production over the history of the water mass, rather than simply showing localized in situ production; since, the concentrations of preformed $\mathrm{N}_{2} \mathrm{O}$ and the effects of conservative mixing were not eliminated (Nevison et al., 2003; Grundle et al., 2012).

In the WPS, the mean of the $\Delta \mathrm{N}_{2} \mathrm{O} / \mathrm{AOU}$ ratio below the $\mathrm{N}_{2} \mathrm{O}$ (a)

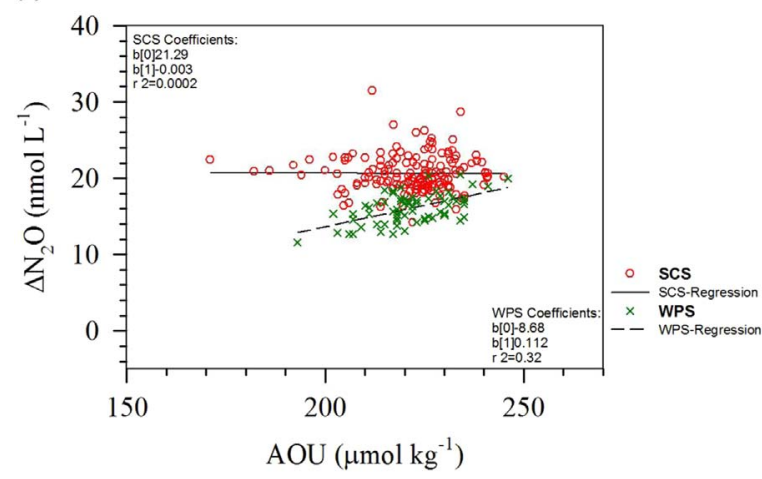

(b)

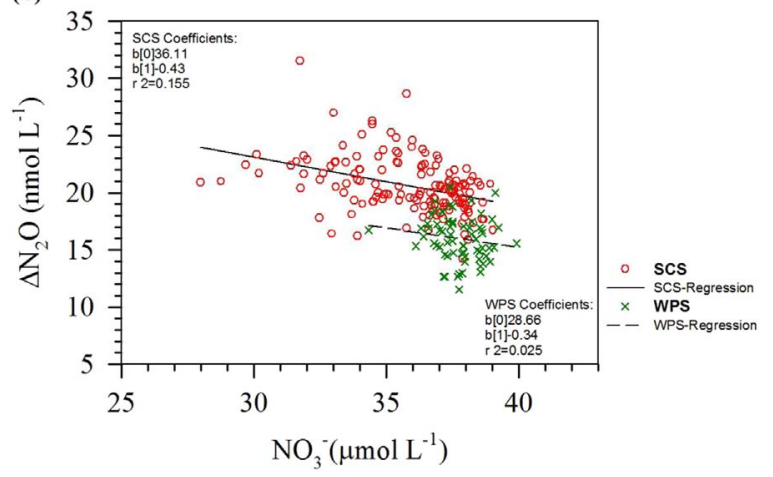

Fig. 11. Relationship between (a) $\Delta \mathrm{N}_{2} \mathrm{O}$ and AOU; (b) $\Delta \mathrm{N}_{2} \mathrm{O}$ and $\mathrm{NO}_{3}{ }^{-}$concentration at depth greater than that of maximum $\mathrm{N}_{2} \mathrm{O}$ concentration in the West Philippines Sea and the South China Sea.

maximum $(800-1000 \mathrm{~m})$ was $0.071 \pm 0.008(\mathrm{n}=49)$, while the mean $\Delta \mathrm{N}_{2} \mathrm{O} / \mathrm{AOU}$ ratio above the $\mathrm{N}_{2} \mathrm{O}$ maximum was $0.091 \pm 0.016(\mathrm{n}=86)$. In the SCS, the mean of the $\Delta \mathrm{N}_{2} \mathrm{O} / \mathrm{AOU}$ ratio below the $\mathrm{N}_{2} \mathrm{O}$ maximum $(600-800 \mathrm{~m})$ was $0.096 \pm 0.013$ $(\mathrm{n}=109)$, while the mean $\Delta \mathrm{N}_{2} \mathrm{O} / \mathrm{AOU}$ ratio above the $\mathrm{N}_{2} \mathrm{O}$ maximum was $0.118 \pm 0.019(n=180)$. In all, biological $\mathrm{N}_{2} \mathrm{O}$ production per mole DO consumed in the SCS was around 23-26\% higher than that in the WPS. This explains why $\mathrm{N}_{2} \mathrm{O}$ distributions in the SCS were about $20 \%$ higher than that in the WPS.

The $\Delta \mathrm{N}_{2} \mathrm{O} / \mathrm{AOU}$ ratios decreased at depths greater than that of the maximum $\mathrm{N}_{2} \mathrm{O}$ concentration in the SCS, maybe because high pressure inhibited the primary nitrification pathway (Butler et al., 1989). However, since DO concentrations in the SCS deep water were at a relatively high level of around $100 \mu \mathrm{mol} \mathrm{L}^{-1}$,

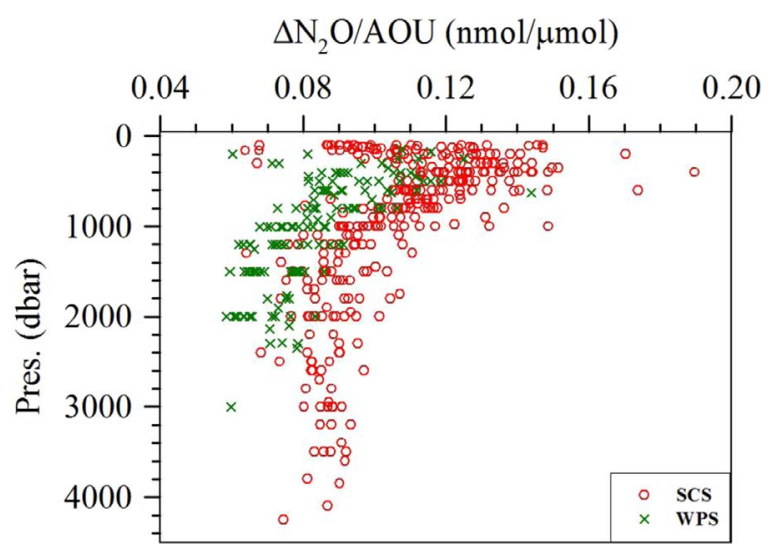

Fig. 12. Vertical distributions of $\Delta \mathrm{N}_{2} \mathrm{O} / \mathrm{AOU}$ ratio in the South China Sea and the West Philippines Sea, obtained at 67 stations during seven cruises between August 2003 and July 2007. 


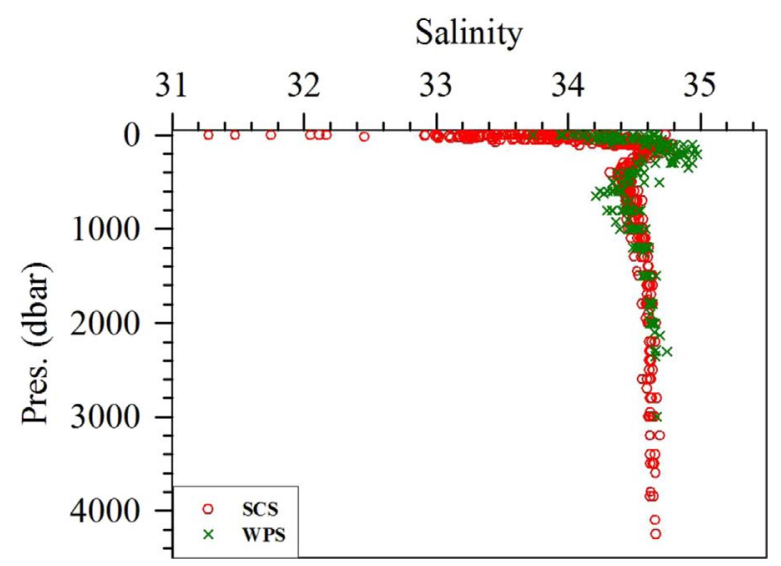

Fig. 13. Vertical distributions of salinity in the South China Sea and the West Philippines Sea, obtained at 114 stations during seven cruises between August 2003 and July 2007.

denitrification did not occur there. The $\mathrm{N}_{2} \mathrm{O}$ concentrations decreased below the depth of the $\mathrm{N}_{2} \mathrm{O}$ maximum in the SCS due to mixing with the WPS deep water, which has low $\mathrm{N}_{2} \mathrm{O}$ concentrations. The $\mathrm{N}_{2} \mathrm{O}$ concentration maximum in the SCS was about $28.85 \mathrm{nmol} \mathrm{L}^{-1}$ and the salinity was around 34.46 (Fig. 13) at depth of around $600-800 \mathrm{~m}$. The $\mathrm{N}_{2} \mathrm{O}$ concentration of the deep water layer (1350-2200 m) in the WPS was $20.43 \mathrm{nmol} \mathrm{L}^{-1}$ and the salinity was 34.62. The WPS deep water flows into the SCS and mixes with the SCS intermediate water, then becomes the SCS deep water with a salinity of 34.60. Calculation based on salinity indicates that the deep water of the SCS is composed of $88 \%$ WPS deep water and $12 \%$ SCS water at the $\mathrm{N}_{2} \mathrm{O}$ maximum
$(0.88 \times 34.62+0.12 \times 34.46$

=34.60). According to the water masses mixing ratio, $21.39 \mathrm{nmol} \mathrm{L}^{-1}$ of the $\mathrm{N}_{2} \mathrm{O}$ concentration in the SCS deep water should have come from physical mixing $(0.88 \times 20.37+0.12 \times$ $28.85=21.39$ ). As a result, $85 \%$ of the $\mathrm{N}_{2} \mathrm{O}$ concentration in the SCS deep water was from physical mixing and $15 \%$ was from biological $\mathrm{N}_{2} \mathrm{O}$ production.

\subsection{Air-sea $\mathrm{N}_{2} \mathrm{O}$ exchange}

During the wet season, the mean surface $\mathrm{N}_{2} \mathrm{O}$ in the SCS was oversaturated and the sea-to-air flux was $5.5 \pm 3.9 \mu \mathrm{mol} \mathrm{m}^{-2} \mathrm{~d}^{-1}$ (Table 2). The mean $\mathrm{N}_{2} \mathrm{O}$ flux in the SCS during the wet season herein exceeds those from the shelf area of northwestern SCS $\left(1.7 \pm 1.6 \mu \mathrm{mol} \mathrm{m}{ }^{-2} \mathrm{~d}^{-1}\right.$; Han et al., 2013) and those from the southern Baltic Sea $\left(2.3-4.0 \mu \mathrm{mol} \mathrm{m}^{-2} \mathrm{~d}^{-1}\right.$; Bange et al., 1998). However, the flux in the SCS is comparable with or is only slightly lower than those from other seas - such as 9.8-17.1 $\mu \mathrm{mol} \mathrm{m}{ }^{-2} \mathrm{~d}^{-1}$ from the East China Sea (Zhang et al., 2008); 4.7$8.4 \mu \mathrm{mol} \mathrm{m} \mathrm{m}^{-2} \mathrm{~d}^{-1}$ from the North Yellow Sea (Yang et al., 2009); $5.2 \mu \mathrm{mol} \mathrm{m}^{-2} \mathrm{~d}^{-1}$ from the northwestern Black Sea (Amouroux et al., 2002), and $6.8-11.9 \mu \mathrm{mol} \mathrm{m}^{-2} \mathrm{~d}^{-1}$ from the north-eastern shelf of the Gulf of Cadiz (Ferrón et al., 2010). The SCS contributes about $0.1 \mathrm{Tg} \mathrm{N}$ to the atmosphere in the wet season which lasts for six months.

The mean surface $\mathrm{N}_{2} \mathrm{O}$ concentration in the WPS in the wet season was undersaturated and the sea-to-air flux was $-1.7 \pm 3.9 \mu \mathrm{mol} \mathrm{m}^{-2} \mathrm{~d}^{-1}$ (Table 2). The WPS, the Golfe du Lion (Marty et al., 2001) and the Adriatic Sea (Leip, 1999) are a few of the marine areas for which $\mathrm{N}_{2} \mathrm{O}$ undersaturations have been reported upon (Bange, 2006).

Table 2

Compilation of $\mathrm{N}_{2} \mathrm{O}$ measurements in various coastal, shelf and marginal seas.

\begin{tabular}{|c|c|c|c|c|c|}
\hline Study area & Date & $\left.\begin{array}{l}\text { Surface } \mathrm{N}_{2} \mathrm{O} \\
(\text { nmol L } \\
-1\end{array}\right)$ & $\begin{array}{l}\text { Saturation } \\
(\%)\end{array}$ & $\begin{array}{l}\text { Sea-to-Air Flux } \\
\left(\mu \mathrm{mol} \mathrm{m}{ }^{-2} \mathrm{~d}^{-1}\right)\end{array}$ & Reference \\
\hline NW Black Sea & Jul.-Aug. 1995 & $8.0 \pm 0.8$ & 110 & $3.1^{\mathrm{a}} ; 5.2^{\mathrm{b}}$ & Amouroux et al., 2002 \\
\hline Caribbean Sea & $\begin{array}{l}\text { June } 1996 \\
\text { Apr. } 1995\end{array}$ & $\begin{array}{l}7.14 \pm 0.21 \\
6.60 \pm 0.55\end{array}$ & $\begin{array}{l}120 \pm 4 \\
114 \pm 9\end{array}$ & $\begin{array}{l}0.014 \pm 0.014^{\mathrm{a}} \\
0.069 \pm 0.070^{\mathrm{a}}\end{array}$ & Morell et al., 2001 \\
\hline Arabian Sea & $\begin{array}{l}\text { Sep.-Oct. } 1986 \\
\text { Apr. - May } 1994 \\
\text { Feb. - Mar. } 1995 \\
\text { Jul. - Aug. } 1995 \\
\text { Aug. } 1996\end{array}$ & & $\begin{array}{l}187 \pm 40 \\
105 \pm 8 \\
132 \pm 5 \\
133 \pm 15 \\
130 \pm 3\end{array}$ & $\begin{array}{l}8.64 \pm 4.32^{\mathrm{a}} \\
0.06 \pm 0.79^{\mathrm{a}} \\
5.11 \pm 4.12^{\mathrm{a}} \\
10.01 \pm 6.68^{\mathrm{a}} \\
15.32 \pm 7.66^{\mathrm{a}}\end{array}$ & $\begin{array}{l}\text { Law and Owens, } 1990 \\
\text { Lal et al., } 1996 \\
\text { Lal and Patra, } 1998\end{array}$ \\
\hline Baltic sea & Aug. 1977-June 1980 & & $123(79-148)$ & & Rönner, 1983 \\
\hline Southern Baltic Sea & June 1994-Apr. 1997 & & $91-312$ & $0.35-3.97^{\mathrm{a}} 0.60-7.08^{\mathrm{b}}$ & Bange et al., 1998 \\
\hline Aegean Sea & July 1993 & $7.02-7.27$ & 103-107 & $1.2-21.0^{\mathrm{a}}$ & Bange et al., 1996b \\
\hline Central North Sea and German Bight & $\begin{array}{l}\text { Sep. } 1991 \\
\text { Sep. } 1992\end{array}$ & $8.4-9.2$ & 99-104 & & Bange et al., 1996a \\
\hline West Bay of Bengal & March-Apr. 1991 & & $125.2(89.3-214)$ & $0.65^{\mathrm{a}}(-1.0-10.7)$ & Naqvi et al., 1994 \\
\hline Eastern Ionian Sea & Jul 1993 & & $107 \pm 3$ & & Bange et al., 1996a \\
\hline Gulf of Lions (Mediterranean Sea) & Jun 1998 & & $86(0-197)$ & & Marty et al., 2001 \\
\hline Gulf of Thermaikos & Apr 1998 & & $171(84-309)$ & & \\
\hline Adriatic Sea & Aug 1996 & & $93(85-100)$ & & Leip, 1999 \\
\hline NE shelf of the Gulf of Cadiz & Jun., Nov. 2006; Feb., May 2007 & $9.4-19.5$ & $120-255$ & $6.8 \pm 6.4^{\mathrm{a}} 11.9 \pm 10.6^{\mathrm{b}}$ & Ferrón et al., 2010 \\
\hline Tokyo Bay & May-Oct. 1994 & $9-139$ & $116-1630$ & $1.5-153^{\mathrm{a}}$ & Hashimoto et al., 1999 \\
\hline North Yellow Sea & $\begin{array}{l}\text { Mar. 2005; Apr., Aug. 2006; } \\
\text { Apr., Oct. } 2007\end{array}$ & 12.0 & & $\begin{array}{l}4.7 \pm 6.8^{\mathrm{a}} \\
8.4 \pm 11.5^{\mathrm{b}}\end{array}$ & Yang et al., 2009 \\
\hline East China Sea & Sep. 2003 & $11.5 \pm 4.5(5.75-24.1)$ & $191 \pm 74(94-382)$ & $9.8 \pm 16.0^{\mathrm{a}} 17.1 \pm 26.4^{\mathrm{b}}$ & Zhang et al., 2008 \\
\hline West Philippines Sea & Aug. 2004; May 2006; Jul. 2007 & $5.19 \pm 1.26$ & $90 \pm 22$ & $-1.7 \pm 3.9^{\mathrm{c}}$ & This study \\
\hline Northwestern South China Sea & Aug. 2008 & $5.51-7.74$ & $99-123$ & $1.1 \pm 1.0^{\mathrm{a}} 1.7 \pm 1.6^{\mathrm{b}}$ & Han et al., 2013 \\
\hline South China Sea & $\begin{array}{l}\text { Aug., Sept., 2003; Jul. 2004; } \\
\text { Jul. 2006; Jul. 2007 }\end{array}$ & $7.59 \pm 1.32$ & $132 \pm 23$ & $5.5 \pm 3.9^{c}$ & This study \\
\hline
\end{tabular}

Flux estimations are follows:

a Liss and Merlivat (1986);

b Wanninkhof (1992);

c Wanninkhof (2014). 
Table 3

$\mathrm{N}_{2} \mathrm{O}$ concentrations, water flux and $\mathrm{N}_{2} \mathrm{O}$ flux of various water masses in the SCS and WPS.

\begin{tabular}{|c|c|c|c|c|c|c|}
\hline & \multicolumn{3}{|l|}{ SCS } & \multicolumn{3}{|l|}{ WPS } \\
\hline & $\begin{array}{l}\text { Avg. Concentration } \\
\text { nmol L-1 }\end{array}$ & $\begin{array}{l}\text { Water Flux } \\
\times 10^{6} \mathrm{t} \mathrm{s}^{-1}\end{array}$ & $\begin{array}{l}\mathrm{N}_{2} \mathrm{O} \text { Flux } \\
\times 10^{6} \mathrm{~mol} \mathrm{~d}^{-1}\end{array}$ & $\begin{array}{l}\text { Avg. Concentration } \\
\mathrm{nmol} \mathrm{L}^{-1}\end{array}$ & $\begin{array}{l}\text { Water Flux } \\
\times 10^{6} \mathrm{t} \mathrm{s}^{-1}\end{array}$ & $\begin{array}{l}\mathrm{N}_{2} \mathrm{O} \text { Flux } \\
\times 10^{6} \mathrm{~mol} \mathrm{~d}^{-1}\end{array}$ \\
\hline Surface Water Layer (0-350 m) & $11.23 \pm 5.17(\mathrm{n}=342)$ & $-13.9 \pm 1.8$ & -13.5 & $6.52 \pm 2.82(\mathrm{n}=122)$ & $12.8 \pm 1.1$ & 7.2 \\
\hline Intermediate water Layer (350-1350 m) & $27.49 \pm 2.88(n=153)$ & $-1.8 \pm 0.4$ & -4.3 & & & \\
\hline Deep Water Layer (1350-2200 m) & & & & $20.37 \pm 1.84(\mathrm{n}=36)$ & $1.2 \pm 0.2$ & 2.1 \\
\hline
\end{tabular}

Positive and negative numbers represent inflow and outflow, respectively.

\subsection{Water mass and $\mathrm{N}_{2} \mathrm{O}$ exchange between the SCS and the WPS}

During the wet season, a net export of surface and intermediate waters from the SCS to the WPS occurs but there is a net import of deep water (Chen et al., 2001). The $\mathrm{N}_{2} \mathrm{O}$ concentration at depths less than $350 \mathrm{~m}$ in the SCS (the SCS surface water layer) was $11.23 \pm 5.17 \mathrm{nmol} \mathrm{L}^{-1}$; that in the WPS (the WPS surface water layer) was $6.52 \pm 2.82 \mathrm{nmol} \mathrm{L}^{-1}$ (Table 3). Chen et al. (2001) calculated the flow of surface water out of the SCS through the Bashi Channel during the wet season at $13.9 \times 10^{6} \mathrm{t} \mathrm{s}^{-1}$, and the flow of WPS into the SCS at $12.8 \times 10^{6} \mathrm{ts}^{-1}$. Overall, the net exports of surface water from the SCS to the WPS carries $6.3 \times 10^{6} \mathrm{~mol} \mathrm{~d}^{-1}$ $\mathrm{N}_{2} \mathrm{O}$ during the wet season.

The SCS intermediate water, as defined by Chen and Huang (1996) based on observational data, is at depths of between 350 and $1350 \mathrm{~m}$, and is a mixture of the upwelled deep water and the surface water. The intermediate water flows out of the SCS at a rate of $1.8 \times 10^{6} \mathrm{t} \mathrm{s}^{-1}$ (Chao et al., 1996; Chen and Huang, 1996) with an $\mathrm{N}_{2} \mathrm{O}$ concentration of $27.49 \pm 2.88 \mathrm{nmol} \mathrm{L}^{-1}$. Thus, the SCS intermediate water exports $4.3 \times 10^{6} \mathrm{~mol} \mathrm{~d}^{-1} \mathrm{~N}_{2} \mathrm{O}$ to the WPS.

The deep water at depths of greater than $1350 \mathrm{~m}$ flows into the SCS year-round at a rate of $1.2 \times 10^{6} \mathrm{t} \mathrm{s}^{-1}$ (Chao et al., 1996; Chen and Huang, 1996). Since the deepest sill that connects the SCS with the WPS is $2200 \mathrm{~m}$ deep, water that is deeper than $2200 \mathrm{~m}$ cannot enter the SCS. The $\mathrm{N}_{2} \mathrm{O}$ concentration of the deep water layer (1350-2200 m) in the WPS was $20.37 \pm 1.84 \mathrm{nmol} \mathrm{L}^{-1}$, so the deep water from the WPS exports $2.1 \times 10^{6} \mathrm{~mol} \mathrm{~d}^{-1} \mathrm{~N}_{2} \mathrm{O}$ to the SCS.

Overall, in the wet season, the SCS exports $8.5 \times 10^{6} \mathrm{~mol} \mathrm{~d}^{-1}$ $\mathrm{N}_{2} \mathrm{O}$ (net value) to the WPS and emits $19.3 \times 10^{6} \mathrm{~mol} \mathrm{~d}^{-1} \mathrm{~N}_{2} \mathrm{O}$ to the atmosphere. Therefore, the SCS exports $\mathrm{N}_{2} \mathrm{O}$ to the WPS and the atmosphere; and the SCS emits a larger amount of $\mathrm{N}_{2} \mathrm{O}$ to the atmosphere than it transports to the WPS.

\section{Conclusions}

The surface waters are oversaturated in $\mathrm{N}_{2} \mathrm{O}$ with respect to the atmosphere in the SCS, and undersaturated in the WPS. During the wet season, the SCS is a source of atmospheric $\mathrm{N}_{2} \mathrm{O}$ at a rate of $5.5 \pm 3.9 \mu \mathrm{mol} \mathrm{m}^{-2} \mathrm{~d}^{-1}$, and the WPS is a sink of atmospheric $\mathrm{N}_{2} \mathrm{O}$ at a rate of $-1.7 \pm 3.9 \mu \mathrm{mol} \mathrm{m} \mathrm{m}^{-2} \mathrm{~d}^{-1}$.

The $\mathrm{N}_{2} \mathrm{O}$ concentration in the water column in the SCS is higher than that in the WPS. The $\mathrm{N}_{2} \mathrm{O}$ concentration in the WPS reached a maximum at a depth of 800-1000 m; the corresponding depth in the SCS was only around $600-800 \mathrm{~m}$, owing to vertical mixing and intensive upwelling. Excess $\mathrm{N}_{2} \mathrm{O}$ correlates positively with $\mathrm{AOU}$ and $\mathrm{NO}_{3}{ }^{-}$suggesting that nitrification is the major mechanism of $\mathrm{N}_{2} \mathrm{O}$ production at depths of less than $1000 \mathrm{~m}$ in the WPS and $800 \mathrm{~m}$ in the SCS. The $\mathrm{N}_{2} \mathrm{O}$ yield from nitrification was $0.053 \%$ in the WPS and $0.070 \%$ in the SCS between a depth of $100 \mathrm{~m}$ and that of the maximum $\mathrm{N}_{2} \mathrm{O}$ concentration, based on correlations of excess $\mathrm{N}_{2} \mathrm{O}$ versus $\mathrm{AOU}$ and $\mathrm{NO}_{3}{ }^{-}$concentrations. This study has established that the SCS emits $\mathrm{N}_{2} \mathrm{O}$ to the atmosphere and exports $\mathrm{N}_{2} \mathrm{O}$ to the WPS.

\section{Acknowledgements}

The authors wish to thank the Ministry of Science and Technology of the ROC, Taiwan (MOST 104-2611-M-110-015 and 1042611-M-110-016) and the Aim for the Top University Program Project (04C030204 and 05C030204), for supporting this research, and the captains and crews of ORI and III for their assistance. This work was also supported by the Erasmus Mundus Joint Doctorates program in Marine and Coastal Management under the UNESCO/ UNITWIn/WiCop research and academic activities. AVB is a senior research associate at the Fonds National de la Recherche Scientifique (FNRS, Belgium). Three anonymous reviewers provided constructive comments which helped strengthening the manuscript.

\section{References}

Amouroux, D., Roberts, G., Rapsomanikis, S., Andreae, M.O., 2002. Biogenic Gas $\left(\mathrm{CH}_{4}, \mathrm{~N}_{2} \mathrm{O}\right.$, DMS) emission to the atmosphere from near-shore and shelf waters of the north-western Black Sea. Estuar. Coast. Shelf Sci. 54, 575-587.

Arévalo-Martínez, D.L., Kock, A., Löscher, C.R., Schmitz, R.A., Bange, H.W., 2015. Massive nitrous oxide emissions from the tropical South Pacific Ocean. Nat. Geosci. 8, 530-533.

Arp, D.J., Stein, L.Y., 2003. Metabolism of inorganic N compounds by ammoniaoxidizing bacteria. Crit. Rev. Biochem. Mol. Biol. 38, 471-495.

Bai, Y., Huang, T.H., He, X., Wang, S.L., Hsin, Y.C., Wu, C.R., Zhai, W., Lui, H.K., Chen, C. T.A., 2015. Intrusion of the Pearl River plume into the main channel of the Taiwan Strait in summer. J. Sea Res. 95, 1-15.

Bange, H.W., 2006. Nitrous oxide and methane in European coastal waters. Estuar. Coast. Shelf Sci. 70, 361-374.

Bange, H.W., 2008. Gaseous nitrogen compounds ( $\mathrm{NO}, \mathrm{N}_{2} \mathrm{O}, \mathrm{N}_{2}, \mathrm{NH}_{3}$ ) in the ocean In: Caponeet et al., D.G. (Ed.), Nitrogen in the Marine Environment. Elsevier, pp. 55-93.

Bange, H.W., Andreae, M.O., 1999. Nitrous oxide in the deep waters of the world's oceans. Glob. Biogeochem. Cycles 13, 1127-1135.

Bange, H.W., Rapsomanikis, S., Andreae, M.O., 1996a. Nitrous oxide in coastal waters. Glob. Biogeochem. Cycles 10, 197-207.

Bange, H.W., Rapsomanikis, S., Andreae, M.O., 1996b. The Aegean Sea as a source of atmospheric nitrous oxide and methane. Mar. Chem. 53, 41-49.

Bange, H.W., Dahlke, S., Ramesh, R., Meyer-Reil, L.-A., Rapsomanikis, S., Andreae, M. O., 1998. Seasonal study of methane and nitrous oxide in the coastal waters of the Southern Baltic Sea. Estuar. Coast. Shelf Sci. 47 (6), 807-817.

Bange, H.W., Bell, T.G., Cornejo, M., Freing, A., Uher, G., Upstill-Goddard, R.C., Zhang, G., 2009. MEMENTO: a proposal to develop a database of marine nitrous oxide and methane measurements. Environ. Chem. 6, 195-197. http://dx.doi.org/ 10.1071/en09033.

Barnes, J., Owens, N.J.P., 1998. Denitrification and nitrous oxide concentrations in the Humber estuary, UK, and adjacent coastal zones. Mar. Pollut. Bull. 37 (3-7), 247-260.

de Bie, M.J.M., Middelburg, J.J., Starink, M., Laanbroek, H.J., 2002. Factors controlling nitrous oxide at the microbial community and estuarine scale. Mar. Ecol.: Prog. Ser. 240, 1-9.

Butler, J.H., Elkins, J.W., Thompson, T.M., 1989. Tropospheric and dissolved $\mathrm{N}_{2} \mathrm{O}$ of the west Pacific and East Indian Oceans during the El Niño Southern Oscillation event of 1987. J. Geophys. Res. 94, 14865-14877.

Cao, Z.-M., Dai, M.-H., Zheng, N., Wang, D.-L., Li, Q., Zhai, W.-D., Meng, F.-F., Gan, J.P., 2011. Dynamics of the carbonate system in a large continental shelf system under the influence of both a river plume and coastal upwelling. J. Geophys. Res. 116, G02010, http://dx.doi.org/10.1029/2010JG001596.

Capone, D.G., 1991. Aspects of the marine nitrogen cycle with relevance to the dynamics of nitrous and nitric oxide, in Microbial Production and Consumption of Greenhouse gases, edited by Rogers J.E., Whitman, W.E., pp. 255-275, Am. Soc. of Microbiol., Washington, D.C. 
Chao, S.Y., Shaw, P.T., Wu, S.Y., 1996. Deep water ventilation in the South China Sea. Deep-Sea Res. 43, 445-466.

Chen, C.T., 1981. Oxygen solubility in seawater. In: Battino, R. (Ed.), Solubility Data Series vol. 7. Pergamon Press, Oxford, New York, Toronto, Sydney, Paris, Frankfurt, pp. 41-55.

Chen, C.T.A., Huang, M.H., 1995. Carbonate chemistry and the anthropogenic $\mathrm{CO}_{2}$ in the South China Sea. Acta Oceanol. Sin. 14, 47-57.

Chen, C.T.A., Huang, M.H., 1996. A mid-depth front separating the South China Sea water and the West Philippine Sea water. J. Oceanogr. 52, 17-25.

Chen, C.T.A., Wang, S.L., Wang, B.J., Pai, S.C., 2001. Nutrient budgets for the South China Sea basin. Mar. Chem. 75, 281-300.

Chen, C.T.A., Hou, W.P., Gamo, T., Wang, S.L., 2006. Carbonate-related parameters of subsurface waters in the West Philippine, South China and Sulu Seas. Mar. Chem. 99, 151-161.

Chen, C.T.A., Yeh, Y.T., Chen, Y.C., Huang, T.H., 2015. Seasonal and ENSO-related interannual variability of subsurface fronts separating West Philippine Sea waters from South China Sea waters near the Luzon Strait. Deep-Sea Res. 103, 13-23.

Chen, C.T.A., Wang, S.L., Lu, X.X., Zhang, S.R., Lui, H.K., Tseng, H.C., Wang, B.J., Huang, H.I., 2008. Hydrogeochemistry and greenhouse gases of the Pearl River, its estuary and beyond. Quat. Int. 186, 79-90.

Codispoti, L.A., 2010. Interesting times for marine $\mathrm{N}_{2}$ O. Science 327 (5971), 1339-1340.

Codispoti, L.A., Yoshinari, T., Devol, A.H., 2005. Suboxic respiration in the oceanic water column. In: Del Giorgo, P.A., Williams, P.J.L.B. (Eds.), Respiration in Aquatic Ecosystems.. Oxford University Press, Oxford, pp. 225-247.

Cohen, Y., Gordon, L.I., 1979. Nitrous oxide production in the ocean. J. Geophys. Res. $84,347-353$

Crutzen, P.J., 1970. The influence of nitrogen oxides on the atmospheric ozone content. Q. J. R. Meteorol. Soc. 96, 320-325.

Crutzen, P.J., 1974. Estimates of possible variations in total ozone due to natural causes and human activities. Ambio 3, 201-210.

Elkins, J.W., Wofsy, S.C., McElroy, M.B., Kolb, C.E., W. A, Kaplan, 1978. Aquatic sources and sinks for nitrous oxide. Nature 275, 602-6606.

England, M.H., 1995. The age of water and ventilation timescales a global ocean model. J. Phys. Oceanogr. 25, 2756-2777.

Ferrón, S., Ortega, T., Forja, J.M., 2010. Nitrous oxide distribution in the northeastern shelf of the Gulf of Cadiz (SW Iberian Peninsula). Mar. Chem. 119, 22-32.

Fluckiger, J., Dallenbach, A., Blunier, T., Stauffer, B., Stocker, T.F., Raynaud, D., Barnola, J.M., 1999. Variations in atmospheric $\mathrm{N}_{2} \mathrm{O}$ concentration during abrupt climatic changes. Science 285 (5425), 227-230.

Freing, A., Wallace, D.W.R., Bange, H.W., 2012. Global oceanic production of nitrous oxide. Philos. Trans. R. Soc. B 367, 1245-1255.

Freing, A., Wallace, D.W.R., Tanhua, T., Walter, S., Bange, H.W., 2009. North Atlantic production of nitrous oxide in the context of changing atmospheric levels. Glob. Biogeochem. Cycles 23, GB4015. http://dx.doi.org/10.1029/2009GB003472.

Gan, J.-P., Li, L., Wang, D.-X., Guo, X.-G., 2009. Interaction of a river plume with coastal upwelling in the northeastern South China Sea. Cont. Shelf Res. 29, $728-740$.

Gebbie, G., Huybers, P., 2012. The mean age of ocean waters inferred from radiocarbon observations: sensitivity to surface sources and accounting for mixing histories. J. Phys. Oceanogr. 42, 291-305.

Goreau, T.J., Kaplan, W.A., Wofsy, S.C., McElroy, M.B., Valois, F.W., Watson, S.W., 1980. Production of $\mathrm{NO}_{2}{ }^{-}$and $\mathrm{N}_{2} \mathrm{O}$ by nitrifying bacteria at reduced concentrations of oxygen. Appl. Environ. Microbiol. 40, 526-532.

Gruber, N., Galloway, J.N., 2008. An earth-system perspective of the global nitrogen cycle. Nature 451, 293-296. http://dx.doi.org/10.1038/nature06592.

Grundle, D.S., Maranger, R., Juniper, S.K., 2012. Upper water column nitrous oxide distributions in the northeast subarctic Pacific ocean. Atmos. -Ocean 50 (4), 475-486.

Tseng, H.C., Chen, C.T.A, Borges, A.V., DelValls, T.A., Chang, Y.C., 2016. Methane distributions and sea-to-air fluxes in the South China Sea and the West Philippines Sea. Cont. Shelf Res., (submitted for publication).

Han, A.-Q., Dai, M.-H., Kao, S.-J., Gan, J.-P., Li, Q., Wang, L.-F., Zhai, W.-D., Wang, L., 2012. Nutrient dynamics and biological consumption in a large continental shelf system under the influence of both a river plume and coastal upwelling. Limnol. Oceanogr. 57, 486-502.

Han, W.-Y., 1998. Marine Chemistry in the South China Sea, Beijing. Science Press,, p. 289 (in Chinese).

Han, Y., Zhang, G.L., Zhao, Y.C., Liu, S.M., 2013. Distributions and sea-to-air fluxes of nitrous oxide in the coastal and shelf waters of the northwestern South China Sea. Estuar. Coast. Shelf Sci. 133, 32-44.

Hashimoto, S., Gojo, K., Hikota, S., Sendai, N., Otsuki, A., A, 1999. Nitrous oxide emissions from coastal waters in Tokyo Bay. Mar. Environ. Res. 47, 213-223.

Herbeck, L.S., Unger, D., Krumme, U., Liu, S.M., Jennerjahn, T.C., 2011. Typhoon-induced precipitation impact on nutrient and suspended matter dynamics of a tropical estuary affected by human activities in Hainan, China. Estuar. Coast. Shelf Sci. 93, 375-388.

Horrigan, S.G., Carlucci, A.F., Williams, P.M., 1981. Light inhibition of nitrification in sea-surface films. J. Mar. Res. 39 (3), 557-565.

Intergovernmental Panel on Climate Change (IPCC), 2013: Working Group I Report The Physical Science Basis. C.2; C.6; C.8, pp. 159-254; pp.473-552; pp. 677731.

Johnson, K.M., Hughes, J.E., Donaghay, P.L., Sieburth, J.M., 1990. Bottle-calibration static head space method for the determination of methane dissolved in seawater. Anal. Chem. 62, 2408-2412.
Lal, S., Patra, P.K., 1998. Variabilities in the fluxes and annual emissions of nitrous oxide fromtheArabian Sea. Glob. Biogeochem. Cycles 12 (2), 321-327.

Lal, S., Patra, P.K., Venkataramani, S., Sarin, M.M., 1996. Distribution of nitrous oxide and methane in the Arabian Sea. Curr. Sci. 71 (11), 894-899.

LaMontagne, M.G., Duran, R., Valiela, I., 2003. Nitrous oxide sources and sinks in coastal aquifers and coupled estuarine receiving waters. Sci. Total Environ. 309, 139-149.

Law, C.S., Owens, N.J.P., 1990. Significant flux of atmospheric nitrous oxide from the northwest Indian Ocean. Nature 346, 826-828.

Leip, A., 1999. Nitrous Oxide $\left(\mathrm{N}_{2} \mathrm{O}\right)$ Emissions From a Coastal Catchment in The Delta of The Po River: Measurements and Modeling of Fluxes From a Mediterranean Lagoon And Agricultural Soils. University Of Bayreuth,, Bayreuth, Germany (unpublished).

Lin, S., Liu, K.K., Chen, M.P., Chen, P., Chang, F.Y., 1992. Distribution of organic carbon in the KEEP area continental margin sediments. Terr. Atmos. Ocean. Sci. 3 (3), 365-378.

Liss, P.S., Merlivat, L., 1986. Air-sea gas exchange rates: introduction and synthesis in the role of air-sea exchange in geochemical cyclings. Mass: D. Reide, Norwell, $113-1127$.

Liu, C.T., Liu, R.J., 1988. The deep current in the Bashi Channel. Acta Oceanogr. Taiwan 20, 107-116.

MacFarling Meure, C., Etheridge, D., Trudinger, C., Steele, P., Langenfelds, R., van Ommen, T., Smith, A., Elkins, J., 2006. Law Dome $\mathrm{CO}_{2}, \mathrm{CH}_{4}$ and $\mathrm{N}_{2} \mathrm{O}$ ice core records extended to 2000 years BP. Geophys. Res. Lett. 33. http://dx.doi.org/ 10.1029/2006GL026152.

Manizza, M., Keeling, R., Nevison, C.D., 2012. On the processes controlling the seasonal cycles of the air-sea fluxes of $\mathrm{O}_{2}$ and $\mathrm{N}_{2} \mathrm{O}$ : A modelling study. Tellus $\mathrm{B}$ 64, 18429.

Marty, D., Bonin, P., Michotey, V., Bianchi, M., 2001. Bacterial biogas production in coastal systems affected by freshwater inputs. Cont. Shelf Res.. 21, 2105-2115.

Middelburg, J.J., Soetaert, K., Herman, P.M.J., Heip, C.H.R., 1996. Denitrification in marine sediments: a model study. Glob. Biogeochem. Cycles 10 (4), 661-673.

Morell, J.M., Capella, J., Mercado, A., Bauza, J., Corredor, J.E., 2001. Nitrous oxide fluxes in Caribbean and tropical Atlantic waters: evidence for near surface production. Mar. Chem. 74, 131-143.

Myhre, G., Shindell, D., Bréon, F.-M., Collins, W., Fuglestvedt, J., Huang, J., Koch, D., Lamarque, J.-F., Lee, D., Mendoza, B., Nakajima, T., Robock, A., Stephens, G., Takemura, T., Zhang, H., 2013: Anthropogenic and natural radiative forcing, in: Climate Change 2013: The Physical Science Basis. Contribution of Working Group I to the Fifth Assessment Report of the Intergovernmental Panel on Climate Change.

Naik, H., Naqvi, S.W.A., Suresh, T., Narvekar, P.V., 2008. Impact of a tropical cyclone on biogeochemistry of the central Arabian Sea. Glob. Biogeochem. Cycles 22, GB3020.

Najjar, R.G., 1992. Marine biogeochemistry. In: Trenberth, K.E. (Ed.), Climate System Modeling. Cambridge University Press, New York, pp. 241-280.

Naqvi, S.W.A., Noronha, R.J., 1991. Nitrous oxide in the Arabian Sea. Deep-Sea Res. 38, 871-890.

Naqvi, S.W.A., Jayakumar, D.A., Nair, M., Kumar, M.D., George, M.D., 1994. Nitrous oxide in the western Bay of Bengal. Mar. Chem. 47, 269-278.

Naqvi, S.W.A., Bange, H.W., Farías, L., Monteiro, P.M.S., Scranton, M.I., Zhang, J., 2010. Marine hypoxia/anoxia as a source of $\mathrm{CH}_{4}$ and $\mathrm{N}_{2} \mathrm{O}$. Biogeosciences 7, 2159-2190.

Naqvi, S.W.A., Yoshinari, T., Jayakumar1, D.A., Altabet, M.A., Narvekar1, P.V., Devol, A.H., Brandes, J.A., Codispoti, L.A., 1998. Budgetary and biogeochemical implications of $\mathrm{N}_{2} \mathrm{O}$ isotope signatures in the Arabian Sea. Nature 394, 462-4464.

Nevison, C., Butler, J.H., Elkins, J.W., 2003. Global distributions of $\mathrm{N}_{2} \mathrm{O}$ and $\Delta \mathrm{N}_{2} \mathrm{O}$ AOU yield in the subsurface ocean. Glob. Biogeochem. Cycles 18, GB1018.

Nevison, C.D., Holland, E.A., 1997. A reexamination of the impact of anthropogenically fixed nitrogen on atmospheric $\mathrm{N}_{2} \mathrm{O}$ and the stratospheric $\mathrm{O}_{3}$ layer. J. Geophys. Res. 102 (25) 519-25,536, 1997.

Nevison, C.D., Weiss, R.F., Erickson III, D.J., 1995. Global oceanic emissions of nitrous oxide. J. Geophys. Res. 100, 15809-15820.

Nitani, H., 1972. Beginning of the Kuroshio. p. 129-163. In: Stommel, H., Yoshida, K. (Eds.), Kuroshio. Univ. Washington Press.

Oudot, C., Andrie, C., Montel, Y., 1990. Nitrous oxide production in the tropical Atlantic Ocean. Deep-Sea Res. 37, 183-202.

Pai, S.-C., Yang, C.-C., Riley, J.P., 1990. Formation kinetics of the pink azo dye in the determination of nitrate in natural waters. Anal. Chim. Acta 232, 345-349.

Pai, S.-C., Gong, G.-C., Liu, K.-K., 1993. Determination of dissolved oxygen in seawater by direct spectrophotometry of total iodine. Mar. Chem. 41, 343-351.

Patra, P.K., Lal, S., Venkataramani, S., de Sousa, S.N., Sarma, V.V.S.S., Sardesai, S., 1999. Seasonal and spatial variability in $\mathrm{N}_{2} \mathrm{O}$ distribution in the Arabian Sea. Deep-Sea Res. Part I 46, 529-543.

Prather, M., et al., 2001. Atmospheric chemistry and greenhouse gases, in Climate Change 2001: the Scientific Basis: Contribution of Working Group I to the Third. In: Houghton, J.T., et al. (Eds.), Assessment Report of the Intergovernmental Panel on Climate Change. Cambridge Univ. Press, New York, pp. 239-287.

Prather, M.J., Holmes, C.D., Hsu, J., 2012. Reactive greenhouse gas scenarios: systematic exploration of uncertainties and the role of atmospheric chemistry. Geophys. Res. Lett. 39, L09803. http://dx.doi.org/10.1029/2012gl051440.

Rönner, U., 1983. Distribution, production and consumption of $\mathrm{N}_{2} \mathrm{O}$ in the Baltic Sea. Geochim. Cosmochim. Acta 47, 2179-2188.

Ravishankara, A.R., Daniel, J.S., Portmann, R.W., 2009. Nitrous oxide $\left(\mathrm{N}_{2} \mathrm{O}\right)$ : the dominant ozone-depleting substance emitted in the 21st Century. Science 326 (5949), 123-125. 
Redfield, A.C., Ketchum, B.H., Richards, F.A., 1963. The influence of organisms on the composition of sea water. In: Hill (Ed.), The Sea Vol 2. Wiley Inter Science, New York, pp. 26-77.

Robinson, A.D., Nedwell, D.B., Harrison, R.M., Ogilvie, B.G., 1998. Hypernutrified estuaries as sources of $\mathrm{N}_{2} \mathrm{O}$ emission to the atmosphere: the estuary of the River Colne, Essex, UK. Mar. Ecol. Prog. Ser. 164, 59-71.

Saikawa, E., Prinn1, R.G., Dlugokencky, E., Ishijima, K., Dutton, G.S., Hall, B.D., Langenfelds, R., Tohjima, Y., Machida, T., Manizza, M., Rigby, M., O’Doherty, S., Patra, P.K., Harth, C.M., Weiss, R.F., Krummel, P.B., van der Schoot, M., Fraser, P.J., Steele, L.P., Aoki, S., Nakazawa, T., Elkins, J.W., 2014. Global and regional emissions estimates for $\mathrm{N}_{2} \mathrm{O}$. Atmos. Chem. Phys. 14, 4617-4641.

Seitzinger, S.P., 1988. Denitrification in freshwater and coastal marine ecosystem: Ecological and geochemical significance. Limnol. Oceanogr. 33, 702-724.

Stein, L.Y., Yung, Y.L., 2003. Production, isotopic composition, and atmospheric fate of biologically produced nitrous oxide. Ann. Rev. Earth Planet. Sci. 31, 329-356.

Strickland, J.D.H., Parsons, T.R., 1972. A Practical Handbook of Seawater Analysis Fisheries Research Board Of Canada,, Ottawa, Canada, p. 310.

Suntharalingam, P., Sarmiento, J.L., 2000. Factors governing the oceanic nitrous oxide distribution: simulations with an ocean general circulation model. Glob. Biogeochem. Cycles 14, 429-454. http://dx.doi.org/10.1029/1999gb900032.

Usui, T., Koike, I., Ogura, N., 1998. Vertical profiles of nitrous oxide and dissolved oxygen in marine sediment. Mar. Chem. 59, 253-2270.

Usui, T., Koike, I., Ogura, N., 2001. $\mathrm{N}_{2} \mathrm{O}$ Production, nitrification and denitrification in an estuarine sediment. Estuar. Coast. Shelf Sci. 52, 769-781.

Walker, J.T., Stow, C., Geron, C., 2010. Nitrous oxide emissions from the Gulf of Mexico hypoxic zone. Environ. Sci. Technol. 44, 1617-1623.

Walsh, J.J., Premuzic, E.T., Gaffney, J.S., Rowe, G.T., Harbottle, G., Stoenner, R.W., Balsam, W.L., Betzer, P.R., Macko, S.A., 1985. Organic storage of $\mathrm{CO}_{2}$ on the continental slope off the mid-Atlantic bight, the southeastern Bering Sea, and the Peru coast. Deep Sea Res. 32, 853-883.

Walter, S., Bange, H.W., Breitenbach, U., Wallace, D.W.R., 2006. Nitrous oxide in the North Atlantic Ocean. Biogeosciences 3 (4), 607-619.

Wanninkhof, R., 1992. Relationship between wind speed and gas exchange over the ocean. J. Geophys. Res. 97 (C5), 7373-7382.

Wanninkhof, R., 2014. Relationship between wind speed and gas exchange over the ocean revisited. Limnol. Oceanogr.: Methods 12, 351-362.

Ward, B.B., 2008. Nitrification in marine systems. In: Capone, D.G., Bronk, D.A., Mullholand, M.R., Carpenter, E.J. (Eds.), Nitrogen in the Marine Environment, second ed. Academic Press, Burlington, MA, pp. 199-262.

Ward, B.B., Glover, H.E., Lipschultz, F., 1989. Chemoautotrophic activity of nitrification in the oxygen minimum zone off Peru. Deep Sea Res. 36, 1031-1051.

Weiss, R.F., Price, B.A., 1980. Nitrous oxide solubility in water and seawater. Mar. Chem. 8, 347-359.
Wrage, N., Velthof, G.L., Van Beusichem, M.L., Oenema, O., 2001. Role of nitrifier denitrification in the production of nitrous oxide. Soil. Biol. Biochem. 33 $1723-1732$.

Xu, J.R., Wang, Y.S., Yin, J.P., Wang, Q.J., Zhang, F.Q., He, L., Sun, C.-C., 2006. Transformation of dissolved inorganic nitrogen species and nitrification and denitrification processes in the near sea section of Zhujiang River. Acta Sci. Circumst. 25, 686-692 (in Chinese).

Yang, J., Zhang, G.L., Zheng, L.X., Zhang, F., 2009. Seasonal variations of fluxes and distributions of dissolved $\mathrm{N}_{2} \mathrm{O}$ in the north yellow sea. Environ. Sci. 30 (3), 656-662 (in Chinese)

Yin, K., Qian, P., Chen, Jv.C., Hsieh, D.P.H., Harrison, P.J., 2000. Dynamics of nutrients and phytoplankton biomass in the Pearl River estuary and adjacent waters of Hong Kong during summer: preliminary evidence for phosphorus and silicon limitation. Mar. Ecol.: Prog. Ser. 194, 295-305.

Yin, K.D., Zhang, J.L., Qian, P.Y., Jian, W.J., Huang, L.M., Chen, J.F., Wu, M.C.S., 2004 Effect of wind events on phytoplankton blooms in the Pearl River estuary during summer. Cont. Shelf Res. 24, 1909-1923.

Yoshida, N., Morimoto, H., Hirano, M., Koike, I., Matsuo, S., Wada, E., Saino, T., Hattori, A., 1989. Nitrification rates and $15 \mathrm{~N}$ abundances of $\mathrm{N}_{2} \mathrm{O}$ and $\mathrm{NO}_{3}{ }^{-}$in the western North Pacific. Nature 342, 895-897.

Yoshinari, T., 1976. Nitrous oxide in the sea. Mar. Chem. 4, 189-202.

Zamora, L.M., Oschlies, A., Bange, H.W., Huebert, K.B., Craig, J.D., Kock, A., Löscher, C. R., 2012. Nitrous oxide dynamics in low oxygen regions of the Pacific: insights from the MEMENTO database. Biogeosciences 9, 5007-5022. http://dx.doi.org 10.5194/bg-9-5007-2012.

Zehr, J.P., Ward, B.B., 2002. Nitrogen cycling in the ocean: new perspectives on processes and paradigms. Appl. Environ. Micro. 68, 1015-1024. http://dx.doi. org/10.1128/aem.68.3.1015-1024.2002

Zhai, W.-D., Dai, M.-H., Chen, B.-S., Guo1, X.-H., Li, Q., Shang, S.-L., Zhang, C.-Y., Cai, W.-J., Wang, D.-X., 2013. Seasonal variations of sea-air $\mathrm{CO}_{2}$ fluxes in the largest tropical marginal sea (South China Sea) based on multiple-year underway measurements. Biogeosciences 10, 7775-7791.

Zhang, G.L., Zhang, J., Ren, J.L., Li, J.B., Liu, S.M., 2008. Distributions and sea-to-air fluxes of methane and nitrous oxide in the North East China Sea in summer. Mar. Chem. 110 (1-2), 42-455.

Zheng, G.M., Tang, D.L., 2007. Offshore and nearshore chlorophyll increases induced by typhoon winds and subsequent terrestrial rainwater runoff. Mar. Ecol.: Prog. Ser. 333, 61-74.

Zheng, L.X., Zhang, G.L., Xu, J., Zhang, F., Zhang, J., 2009. Distribution and air-sea fluxes of $\mathrm{N}_{2} \mathrm{O}$ in South China Sea in spring. Mar. Environ. Sci. 28 (3), 233-2237 (in Chinese).

Zhu, Z.Y., Zhang, J., Wu, Y., Lin, J., 2006. Bulk particulate organic carbon in the East China Sea: tidal influence and bottom transport. Prog. Oceanogr. 69, 37-60. 